\title{
Are amyloid diseases caused by protein aggregates that mimic bacterial pore-forming toxins?
}

\author{
Hilal A. Lashuel'** and Peter T. Lansbury Jr. ${ }^{2 *}$ \\ ' Laboratory of Molecular Neurobiology and Neuroproteomics, Brain Mind Institute, Ecole Polytechnique \\ Federale de Lausanne (EPFL), CH-I0I5 Lausanne, Switzerland \\ ${ }^{2}$ Harvard Center for Neurodegeneration and Repair, Center for Neurologic Diseases, Brigham and Women's \\ Hospital and Department of Neurology, Harvard Medical School, 65 Landsdowne St, Cambridge, MA 02139, USA
}

\begin{abstract}
Protein fibrillization is implicated in the pathogenesis of most, if not all, ageassociated neurodegenerative diseases, but the mechanism(s) by which it triggers neuronal death is unknown. Reductionist in vitro studies suggest that the amyloid protofibril may be the toxic species and that it may amplify itself by inhibiting proteasome-dependent protein degradation. Although its pathogenic target has not been identified, the properties of the protofibril suggest that neurons could be killed by unregulated membrane permeabilization, possibly by a type of protofibril referred to here as the 'amyloid pore'. The purpose of this review is to summarize the existing supportive circumstantial evidence and to stimulate further studies designed to test the validity of this hypothesis.
\end{abstract}

\section{Introduction 168}

2. What is the significance of the shared structural properties of disease-associated protein fibrils? 169

2.I Mechanism of amyloid fibril formation in vitro 172

2.I.I In vitro fibril formation involves transient population of ordered aggregates of intermediate stability, or protofibrils 172

\section{Toxic properties of protofibrils 173}

3.I Protofibrils, rather than fibrils, are likely to be pathogenic 173

3.2 The toxic protofibril may be a mixture of related species 174

3.3 Morphological similarities of protofibrils suggest a common mechanism of toxicity 175

3.4 Are the amyloid diseases a subset of a much larger class of previously unrecognized protofibril diseases? 175

3.5 Fibrils, in the form of aggresomes, may function to sequester toxic protofibrils 175

\section{Amyloid pores, a common structural link among protein aggregation} neurodegenerative diseases 176

4.I Mechanistic studies of amyloid fibril formation reveal common features, including pore-like protofibrils 176
4.I.I Amyloid- $\beta(\mathrm{A} \beta)$ (Alzheimer's disease) 176
4.1.2 $\alpha$-Synuclein (PD and diffuse Lewy body disease) 178
4.I.3 ABri (familial British dementia) $\quad 179$

* Correspondence may be addressed to either author.

Email: hilal.lashuel@epfl.ch or plansbury@rics.bwh.harvard.edu 
4.I.4 Superoxide dismutase-I (amyotrophic lateral sclerosis) $\quad 179$

4.I.5 Prion protein (Creutzfeldt-Jakob disease, bovine spongiform encephalopathy, etc.) $\quad$ I 80

4.I.6 Huntingtin (Huntington's disease) 180

4.2 Amyloidogenic proteins that are not linked to disease also from pore-like protofibrils |8|

4.3 Amyloid proteins form non-fibrillar aggregates that have properties of protein channels or pores $|8|$

4.3.I A $\beta$ 'channels' |8|

4.3.2 $\alpha$-Synuclein 'pores' 182

4.3.3 PrP 'channels' 182

4.3.4 Polyglutamine 'channels' 183

4.4 Nature uses $\beta$-strand-mediated protein oligomerization to construct pore-forming toxins

\section{Mechanisms of protofibril induced toxicity in protein aggregation diseases $\mathbf{1 8 5}$}

5.I The amyloid pore can explain the age-association and cell-type selectivity of the neurodegenerative diseases 185

5.2 Protofibrils may promote their own accumulation by inhibiting the proteasome 186

\section{Testing the amyloid pore hypothesis by attempting to disprove it 187}

\section{Acknowledgments 188}

\section{References 188}

\section{Introduction}

A compelling circumstantial case can be made that amyloid fibril formation is a primary cause of neurodegeneration in Alzheimer's disease (AD), Parkinson's disease (PD), prion diseases, and related diseases (see Table 1) (Rochet \& Lansbury, 2000; Stefani \& Dobson, 2003). Supporting evidence for this case, is derived from (1) pathology: fibrillar protein aggregates often colocalize with neuronal loss, (2) genetics: the gene encoding the fibrillar protein is linked to disease (autosomal dominant mutations cause familial disease, polymorphisms can be susceptibility factors, and some haplotypes are linked to risk), (3) animal modeling: overexpression of the fibrillar protein reproduces many features of the human disease, and (4) biophysics: proteins containing disease-associated mutations aggregate more rapidly than wild-type proteins. However, the mechanism by which amyloid fibril formation causes neurodegeneration and the identity of the pathogenic species have not been determined. It is not possible to directly observe the pathogenic event. Therefore, one is left to extrapolate from simplified models in order to produce a working hypothesis, which can then be tested experimentally. The design of a successful therapeutic strategy based on a working hypothesis will be taken as a 'proof' of its veracity.

The pathogenic pathway is likely to be much more complicated than an evolutionarily optimized process like, say, ribosome assembly. Furthermore, there is no a priori reason to assume that cell death in neurodegenerative disease occurs by a single mechanism or that, if protein aggregates are responsible, a single species is capable of acting alone as the pathogenic trigger. Despite these caveats, this review will apply Occam's razor and start with the working hypothesis that a single species of protein aggregate may be responsible for initiating a cascade of events that culminate in neurodegeneration. It is our hope that this review will stimulate others to design experiments to test the relevance, or lack of thereof, of this working hypothesis. 
The majority of research in the field of neurodegeneration has focused on the cause of neuronal death, rather than on the identity of the neurotoxic species. This review will focus on in vitro studies aimed at the characterization of an intermediate on the amyloid pathway as one potential toxic species. This review is based on the premise that understanding the structures of the protein aggregates and the dynamics of their interconversion in vitro, can establish potential links between aggregation and toxicity. The key to such an approach is to allow genetic information, especially regarding autosomal dominant (gain of function) mutations, to guide these experiments. Before summarizing these studies, it is important to emphasize that any reductionist approach must ultimately explain essential features of the in vivo process that it is seeking to elucidate. In the case of neurodegeneration, these are:

(1) Aging is one of the strongest susceptibility factor for all of the neurodegenerative diseases. Even those that are purely genetic, like Huntington's disease, are primarily adult-onset. This does not necessarily mean that the pathogenic process takes a long time, but only that neurons become more susceptible to occurrence of a pathogenic event as they age.

(2) All of these diseases show selectivity to particular types of neurons (hence the diverse symptoms).

(3) Mutations cause early-onset forms of these diseases that are transmitted in an autosomal dominant manner.

Points (2) and (3) are linked, since different mutations in the same protein can produce distinct clinical entities that affect different neuronal subpopulations (three examples are fatal insomnia, which results from a point mutation in the prion protein (Gambetti et al. 1995), hereditary cerebral haemorrhage with amyloidosis of the Dutch type, caused by a mutation in amyloid precursor protein (APP)/A $\beta$ (Maat-Schieman et al. 1992), and dementia with Lewy bodies, caused by a mutation in $\alpha$-synuclein (Zarranz et al. 2004)).

Several lines of evidence suggest that in vitro amyloid fibril formation mimics the in vivo process: (a) fibrils formed in vitro strongly resemble those in diseased tissues (Sunde et al. 1997), (b) protofibrillar intermediates, first detected in vitro, and later in vivo (see Table 1) exhibit strikingly similar structural and neurotoxic properties (Roher et al. 1996) and (c) the specificity of in vitro assembly is reflected in vivo (Wetzel, 1994; Helms \& Wetzel, 1996; Rajan et al. 2001; Kheterpal et al. 2003). Taken together, these observations suggest that structural and mechanistic clues derived from in vitro studies are relevant to the role of protein fibrillogenesis in neurodegenerative diseases and may provide molecular targets for the design of desperately needed therapeutic agents.

\section{What is the significance of the shared structural properties of disease-associated protein fibrils?}

Approximately 24 human proteins form amyloid fibrils in vivo (Stefani \& Dobson, 2003). These proteins are unrelated at the level of primary structure, consistent with the finding that many proteins with no connection to disease can form amyloid fibrils with a common core structure in vitro, suggesting that the amyloid fibril is an intrinsically stable structure (Dobson, 2001). Amyloid fibrils are not crystalline, so their structural similarity is based on lower-resolution approaches: X-ray fibril diffraction, electron and atomic force microscopy, and their ability to bind histopathological dyes like Congo Red and Thioflavin T (Sunde et al. 1997). The structural convergence among various amyloid fibrils is also corroborated by the findings that antibodies 
Table 1. A summary of studies examining the structure and formation of protofibrils, including amyloid pores by several amyloid-forming priteins in vitro, cell cultures and in vivo grouped according to the amyloid disease to which they are relevant. Due to space limitations only the most relevant references are cited

\begin{tabular}{|c|c|c|c|c|c|}
\hline Disease & $\begin{array}{l}\text { Amyloid-forming } \\
\text { proteins and peptides }\end{array}$ & $\begin{array}{l}\text { Evidence for } \\
\text { protofibrils in vitro }\end{array}$ & $\begin{array}{l}\text { Evidence for protofibrils } \\
\text { In cell culture and in vivo }\end{array}$ & $\begin{array}{l}\text { Evidence for annular } \\
\text { structures/amyloid pores }\end{array}$ & $\begin{array}{l}\text { Evidence for } \\
\text { channel/pore activity }\end{array}$ \\
\hline \multirow[t]{3}{*}{$\begin{array}{l}\text { Alzheimer's } \\
\text { disease }\end{array}$} & $\mathrm{A} \beta$ 1-40 (WT) & $\begin{array}{l}\text { Goldsbury et al. 2005; } \\
\text { Harper et al. 1997a, b, } \\
\text { 1999; Huang et al. 2000; } \\
\text { Kayed et al. 2004; } \\
\text { Lambert et al. 1998; Stine } \\
\text { et al. 2003; Walsh et al. } \\
\text { 1997, 1999; Yong et al. } \\
\text { 2002) }\end{array}$ & $\begin{array}{l}\text { Funato et al. 1999; Gong } \\
\text { et al. 2003; Kuo et al. 1996; } \\
\text { Lambert et al. 2001; } \\
\text { Pitschke et al. 1998; } \\
\text { Roher et al. } 1996\end{array}$ & $\begin{array}{l}\text { Hafner et al. 2001; Kayed } \\
\text { \& Glabe, 2004; Klug et al. } \\
\text { 2003; Lashuel et al. 2002b, } \\
\text { 2003 }\end{array}$ & $\begin{array}{l}\text { Alarcon et al. 2006; Arispe } \\
\text { et al. 1993a, b, 1994, 1996; } \\
\text { Kagan et al. 2002; } \\
\text { Kawahara \& Kuroda, } \\
\text { 2000, 2001; Kawahara } \\
\text { et al. 2000; Kourie et al. } \\
\text { 2001b; Lin } \text { et al. } 1999 \text {; } \\
\text { Singer \& Dewji, } 2006\end{array}$ \\
\hline & $\mathrm{A} \beta 1-40(\mathrm{E} 22 \mathrm{G})$ & $\begin{array}{l}\text { Dahlgren et al. 2002; } \\
\text { Lashuel et al. 2002b, 2003; } \\
\text { Nilsberth et al. } 2001\end{array}$ & $\begin{array}{l}\text { Morishima-Kawashima } \\
\text { \& Ihara, 1998; Podlisny } \\
\text { et al. 1995; Walsh et al. } \\
\text { 2000, } 2002\end{array}$ & Lashuel et al. 2002b, 2003 & \\
\hline & $\begin{array}{l}\mathrm{A} \beta 1-42 \\
\text { (WT \& E22G) }\end{array}$ & $\begin{array}{l}\text { Dahlgren et al. 2002; } \\
\text { El-Agnaf et al. 2000; } \\
\text { Parbhu et al. 2002; Roher } \\
\text { et al. 1996; Stine et al. } \\
\text { 2003; Wang et al. 2002a }\end{array}$ & & $\begin{array}{l}\text { Chromy et al. 2003; Kayed } \\
\text { et al. 2004; Lashuel } \text { et al. } \\
\text { 2003; Lin et al. } 2001\end{array}$ & $\begin{array}{l}\text { Bahadi et al. 2003a; Bhatia } \\
\text { et al. 2000; Hirakura et al. } \\
\text { 1999; Lin et al. 2001; Rhee } \\
\text { et al. } 1998\end{array}$ \\
\hline
\end{tabular}


Familial British

dementia

Dialysis-associated amyloidosis

Secondary systemic amyloidoses

Prion-related

diseases

\section{MHM2 PrP $106(\Delta 23-88$ and $\Delta 141-176$}

Prion, PrP 106-126

84-146

SHa PrP (90-232)

PrP (23-231)

(polyglutamine)

Huntington'

disease

Amyotrophic lateral sclerosis

Superoxide dismutase-1 (W'T \& A4V, G37R G85R)

Senile \& familal

Transthyretin

amyloidosis

Type II diabetes
El-Agnaf et al. 2001a, b;

Srinivasan et al. 2003

Kad et al. 2003

Wang et al. 2002b

Baskakov et al. 2000

Kayed \& Glabe, 2004

Sokolowski et al. 2003

Baskakov et al. 2002 ;

Lu \& Chang, 2002

Vendrely et al. 2005

Poirier et al. 2002a

Chung, 2003; Rakhit et al. 2002, 2004; Ray et al. 2004

Cardoso et al. 2002a, b;

Kaved et al. 2003, 2004;

Lashuel et al. 1998, 1999

Anguiano et al. 2002; Green Butler et al. 2003; et al. 2003; Green, 2004; de Koning et al. 1994;

Kaved \& Glabe, 2004;

Kayed et al. 2003; Porat

et al. 2003; Rhoades \&

Gafni, 2003

P53

Equine lysozyme

Ishimaru et al. 2003

Insulin
Wang et al. 2002b

Riesner et al. 1996;

Supattapone et al. 1999

Kayed \& Glabe, 2004

Sokolowski et al. 2003

Kayed \& Glabe, 2004

Turner et al. 2003

Sousa et al. 2001, 2002 ;

Teng et al. 2001

Janson et al. 1996;

O'Brien et al. 1994

Chung, 2003; Ray et al. 2004

Kayed \& Glabe, 2004

Janson et al. 1999;

Anguiano, 2002;
Quist et al. 2005

Hirakura \& Kagan, 2001

Hirakura et al. 2002

Kawahara et al. 2000;

Kourie, 2002; Kourie \&

Culverson, 2000;

Kourie et al. 2001a, 2003;

Lin et al. 1997

Hirakura et al. 2000b

Bahadi et al. 2003b, c

Hirakura et al. 2000a;

Kagan et al. 2001;

Monoi et al. 2000

Demuro et al. 2005

Kayed et al. 2004

Azimov et al. 2001

Kaved \& Glabe, 2004;

Porat et al. 2003

Ishimaru et al. 2003

Malisauskas et al. 2003

Dzwolak et al. 2005 

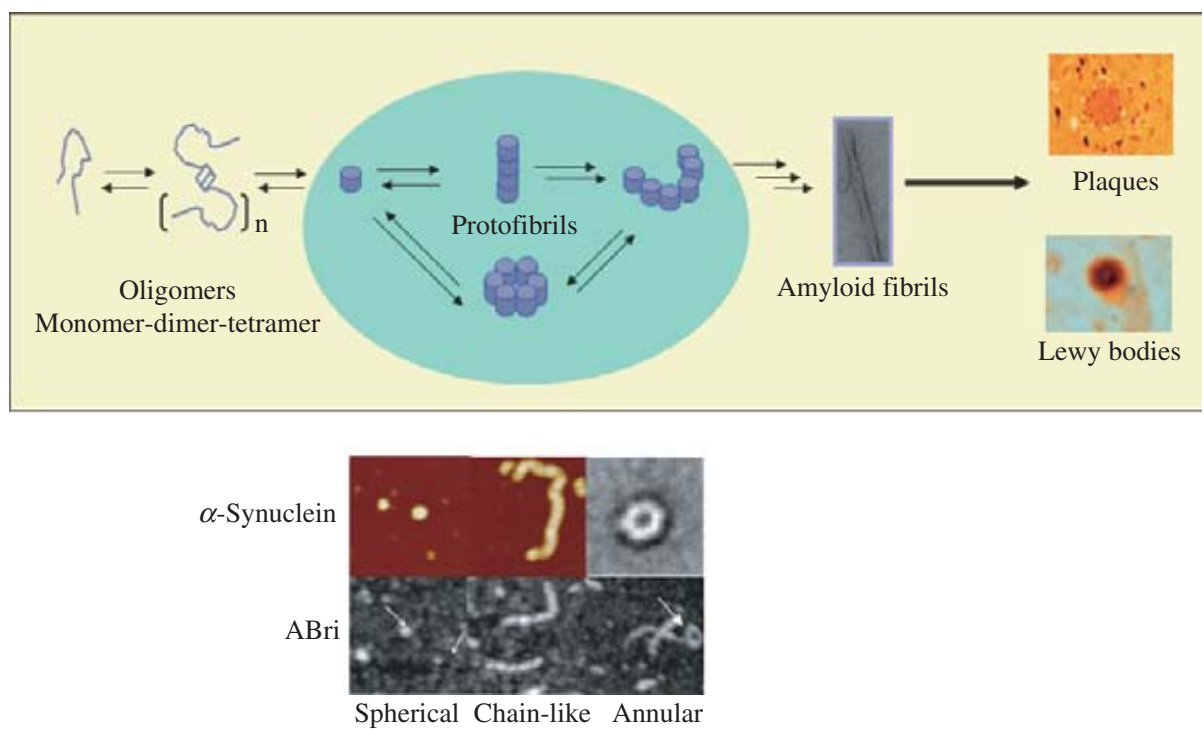

Fig. 1. In vitro fibril formation involves transient population of ordered aggregates, or protofibrils. Schematic representation summarizing the quaternary structural species populated during amyloid fibril formation in vitro and are thought to form during protein fibrillogenesis and deposition in vivo. For simplicity, only the most commonly observed (globular, chain-like and annular structures) protofibrillar structures are shown. (The ABri images were kindly provided by Dr Michael Zagorski.)

raised against the fibrillar form of the amyloidogenic protein amyloid- $\beta$ (A $\beta$ ) recognize amyloid fibrils derived from other amyloid-forming proteins (O’Nuallain \& Wetzel, 2002). The shared conformational epitopes have not been identified, but may be involved in pathogenesis. Moreover, the structural similarities suggest a shared mechanism of amyloid fibril formation.

\section{I Mechanism of amyloid fibril formation in vitro}

\section{I.I In vitro fibril formation involves transient population of ordered aggregates of intermediate stability, or protofibrils}

In order to form an amyloid fibril, proteins must adopt a $\beta$-sheet rich conformation(s). This may involve induction of structure in a disordered monomer, or the partial unfolding of a $\beta$-sheet-containing globular protein. The $\beta$-sheet-rich species has a high propensity to aggregate/ fibrillize (Kelly, 1998). In vitro amyloid fibril formation does not proceed via a simple two-state, 'intermediate-less' mechanism akin to microtuble formation from tubulin (these processes have evolved to be efficient and non-toxic), although that model can be instructive (Jarrett \& Lansbury, 1993). Rather, discrete $\beta$-sheet rich oligomeric intermediates appear before fibrils form and disappear upon fibril formation (Harper et al. 1997a; Walsh et al. 1997; Lambert et al. 1998) (Fig. 1). These are collectively designated protofibrils. Protofibrils are more stable than the monomer, but less stable than the fibrillar product. They appear to be obligate intermediates in fibril formation; the transient formation of protofibrils has been observed in every wellcharacterized in vitro case, suggesting that they are obligate intermediates that are likely to exist, albeit transiently, in vivo. 


\section{Toxic properties of protofibrils}

\section{I Protofibrils, rather than fibrils, are likely to be pathogenic}

The presence of amyloid fibrils in the post-mortem brains of demented patients led to the first description of $\mathrm{AD}$ and resulted in the hypothesis that fibrils themselves are the primary pathogenic species. This hypothesis fails to explain several important pathological and clinical characteristics of AD, raising the possibility that a species other than amyloid fibrils could be the toxic species (Goldberg \& Lansbury, 2000). First, there is no correlation between the amounts of fibrillar A $\beta$ deposits at autopsy and the clinical severity of AD (Lemere et al. 1996; Terry et al. 1991). Such a correlation does exist between 'soluble $A \beta$ ' (monomers plus protofibrils) in the brain and early cognitive dysfunction (Lue et al. 1999; McLean et al. 1999; Naslund et al. 2000). Second, transgenic animals that overproduce APP exhibit neuronal and behavioral abnormalities before amyloid plaques can be detected (Chui et al. 1999; Hsia et al. 1999; Moechars et al. 1999; Mucke et al. 2000). Third, inhibiting A $\beta$ amyloid fibril formation does not necessarily attenuate $\mathrm{A} \beta$-associated toxicity towards cultured neurons (Aksenova et al. 1996; Stege et al. 1999). Fourth, one autosomal dominant form of $\mathrm{AD}$ results from a mutation $[\mathrm{APP}(\mathrm{E} 693 \mathrm{G})=\mathrm{A} \beta(\mathrm{E} 22 \mathrm{G})]$ that decreases $\mathrm{A} \beta$ production in vivo and promotes protofibril formation and toxicity in vitro (Nilsberth et al. 2001; Lashuel et al. 2003; Whalen, 2005). Fifth, in some AD transgenic mice, vaccination with an $\mathrm{A} \beta$-directed antibody prevented or reversed age-dependent memory decline without reducing the amyloid burden (Morgan et al. 2000) [in other cases, vaccination has been shown to reduce behavioral and cognitive deficits and the amyloid burden (Janus et al. 2000; Morgan et al. 2000)]. Finally, A $\beta$ aggregates with properties that are indistinguishable from A $\beta$ protofibrils formed in vitro have been found in human CSF, human cerebral cortex (McLean et al. 1999), and in neuritic amyloid plaques from AD brains (Roher et al. 1996), raising the possibility that soluble prefibrillar oligomeric species, rather than the fibrils, could be the pathogenic species in $\mathrm{AD}$ and related amyloid diseases. Consistent with this hypothesis, oligomeric (dimer, trimers and tetramers) low-molecular-weight oligomers (Walsh et al. 2002; Wang et al. 2004; Cleary et al. 2005; Townsend et al. 2006) and protofibrillar forms of $\mathrm{A} \beta$ altered neuronal function and/or caused neuronal death in culture (Lambert et al. 1998; Hartley et al. 1999; Walsh et al. 2002; Whalen et al. 2005).

The toxic protofibril hypothesis also explains features of PD and other neurodegenerative diseases that are inconsistent with the fibril being the pathogenic species (Goldberg \& Lansbury, 2000; Caughey \& Lansbury, 2003; Silveira et al. 2005). In PD, fibrillar intraneuronal inclusions comprising $\alpha$-synuclein, known as Lewy bodies (LBs), are an invariant feature of sporadic and autosomal dominant forms of PD, but are absent in autosomal recessive juvenile Parkinsonism (AJRP) (Shimura et al. 2001). It is likely that AJRP brains have such high levels of protofibrils that complete neurodegeneration occurs before LBs have a chance to form [AJRP results from a deletion in the parkin gene; point mutations produce a later-onset form of PD that is characterized by LBs (Kitada et al. 1998)]. Elevated levels of soluble oligomeric forms of $\alpha$-synulcien have been detected in plasma samples of PD patients compared to controls (El-Agnaf et al. 2006). Similarly, transgenic mice that overexpress the human $\alpha$-synuclein protein become symptomatic (movement disorder plus dopaminergic abnormalities) but do not produce fibrillar deposits (Masliah et al. 2000). Furthermore, virus-mediated overexpression of human $\alpha$-synuclein into the substantia nigra of rats (Kirik et al. 2002; Lo Bianco et al. 2002) and primates (Kirik et al. 2003 ) results in selective dopaminergic neuronal death with non-fibrillar, $\alpha$-synuclein-containing inclusions. In vitro studies of $\alpha$-synuclein aggregation provide possible hints as to the underlying 
situation: mixtures of human and mouse $\alpha$-synuclein (as exist in the transgenic mouse brain) accumulate protofibrils, but fibrillize very slowly (Rochet et al. 2000). Interestingly, virusmediated expression of rat $\alpha$-synuclein in rat brain results in aggregation, but no neurodegeneration (Kirik et al. 2002; Lo Bianco et al. 2002). Further characterization of the aggregates formed by human and rat $\alpha$-synuclein could provide important insights into the role of $\alpha$-synuclein aggregation in the degeneration of dopaminergic neurons.

Other neurodegenerative diseases fail to support the proposal that amyloid fibrils are pathogenic. Prion protein (PrP) fibrils are observed in some prion diseases, but are not an invariant feature (Chiesa \& Harris, 2001). In yeast and mouse models of prion disease, toxicity was produced in the absence of the stable, protease-resistant aggregated form of the prion protein (PrP-Sc) (Ma \& Lindquist, 2002; Ma et al. 2002). A transgenic mouse model of a familial prion disease became symptomatic before PrP-Sc could be detected (Chiesa et al. 2003). Recent studies by Caughey and co-workers suggest that the most infectious PrP particles represent protofibrillar particles with molecular masses ranging from $300-600 \mathrm{kDa}$ (corresponding to $14-28 \operatorname{Pr} \mathrm{P}$ molecules) (Silveira et al. 2005). Finally, in systemic amyloid diseases, where amyloid was thought to produce disease by physically interfering with organ function, studies by Reixach et al. suggest a primary pathogenic role for protofibrils in initiating cytotoxicity and organ dysfunction (Reixach et al. 2004). For example, non-fibrillar aggregates of transthyretin (TTR), a protein associated with systemic amyloidosis and familial amyloid polyneuropathy (FAP), have been detected in transgenic mice expressing wild-type and mutant TTR (Teng et al. 2001) and in the nerves of FAP patients (Sousa et al. 2001, 2002). These aggregates were linked to significant clinical pathology early in the disease before the fibrillar deposits could be detected.

\subsection{The toxic protofibril may be a mixture of related species}

In an effort to more precisely identify the neurotoxic protein aggregate, cell culture models of extracellular toxicity have been utilized. Although these simplified models allow more detailed analysis, their relevance to $\mathrm{AD}$ is debatable. Given that caveat, as well as the fact that $\mathrm{A} \beta$ oligomers added to cell culture media are heterogeneous (Lashuel et al. 2003; Goldsbury et al. 2005) and are likely to change during the course of an experiment, there is remarkable agreement among these studies that the protofibril, and not the monomer or the fibril, is a toxic entity (Lambert et al. 1998; Hartley et al. 1999; White et al. 2005; Townsend et al. 2006). In the case of $\mathrm{A} \beta$, the amyloid protein of $\mathrm{AD}$, globular oligomers (designated ADDLs) were toxic to cultured neurons (Lambert et al. 1998) and inhibited hippocampal long-term potentiation (LTP) when introduced to brain slices (Wang et al. 2002a). Globular oligomers of similar sizes (based on AFM and EM measurement) have been described by other research groups and were shown to be toxic to cultured neurons (Barghorn et al. 2005). In a related study, small spherical and chain-like $\mathrm{A} \beta$ protofibrils (but not monomer, dimer, trimer) induced acute electrophysiological changes and progressive neurotoxicity in cortical neurons (Hartley et al. 1999). Large spherical aggregates of $\mathrm{A} \beta$ (average diameter of $>10 \mathrm{~nm}$ ), termed amylospheroids, exhibited significantly higher toxicity than small spherical $\mathrm{A} \beta$ oligomers $(<10 \mathrm{~nm}$ ) (Hoshi et al. 2003). A $\beta 42$ forms spherical aggregates (diameter $>10 \mathrm{~nm}$ ) more rapidly and exhibits significantly more ( $>100$-fold) toxicity to neuronal cultures than those formed by $\mathrm{A} \beta 40$. Similar, apparently spherical structures with diameters ranging from $8-24 \mathrm{~nm}$ have also been observed as transient intermediates during the fibrillogenesis of the arctic variant (E22G) of A $\beta 40$ and A $\beta 42$ (Lashuel et al. 2003), $\alpha$-synuclein (Lashuel et al. 2002a) and mutant SOD1 (Ray et al. 2004). The toxicity of TTR towards cultured 
cells is also linked to a non-fibrillar oligomeric species, possibly an octamer (Reixach et al. 2004). Finally, it is probable that the protofibril structure, rather than the protein primary sequence, produces toxicity. For example, small spherical protofibrils, formed in vitro by an amyloidogenic SH3 domain from bovine phosphatidyl-inositol-3 kinase (which is not linked to any disease) are toxic to cultured cells (Bucciantini et al. 2002).

\subsection{Morphological similarities of protofibrils suggest a common mechanism of toxicity}

The shared morphological and toxic properties of amyloid protofibrils suggest that toxicity depends on shared structural features. Consistent with this hypothesis, antibodies raised against protofibrillar $\mathrm{A} \beta$ were reported to recognize protofibrillar species derived from other amyloidogenic proteins (e.g. $\alpha$-synuclein, polyglutamine, TTR, IAPP, lysozyme, human insulin, and PrP106-126), but not monomeric or fibrillar forms of these proteins (Kayed et al. 2003). These antibodies also inhibit the toxicity of these proteins. These findings support detailed structural studies of protofibrils, some of which are summarized below. Furthermore, These observations raise the possibility that these diverse (with respect to sequence, at least) structures may exert their toxicity through common mechanisms. It may be that an intermediate on the assembly pathway that is in equilibrium with the protofibril could be the toxic species. The most likely candidates are low-molecular-weight oligomers (e.g. dimers, trimers or tetramers) or a highmolecular-weight protofibrillar species, most likely the $4 \mathrm{~nm}( \pm 1 \mathrm{~nm})$ spherical species. This is consistent with biophysical studies (AFM and EM) demonstrating that these spheres are the precursors to the chain-like and annular protofibrillar structures and appear to exist in equilibrium with the large spherical aggregates $(8-70 \mathrm{~nm})$. Several laboratories have demonstrated that these species are capable of self-assembling into pore-like structures on artificial or biological membranes (Lin et al. 2001; Ding et al. 2002).

\subsection{Are the amyloid diseases a subset of a much larger class of previously unrecognized protofibril diseases?}

The hypothesis that small protofibrillar aggregates are pathogenic has an interesting corollary: there may be many other diseases that, like ARJP, are not characterized by easily detected protein aggregates. Unlike ARJP, which is genetically and clinically linked to the amyloid disease PD, these diseases may not be recognized as involving protein aggregation at all. In contrast to our expectation that the primary sequence efficiently directs protein folding, a significant portion of newly synthesized proteins ( $35 \%$ ) are not correctly folded in vivo (Schubert et al. 2000). We expect that many more protein aggregation-driven pathologies remain to be discovered.

\subsection{Fibrils, in the form of aggresomes, may function to sequester toxic protofibrils}

According to the toxic protofibril hypothesis, the role of the amyloid fibril is uncertain; it could have some greatly reduced toxicity, it could be inert, or it could protect neurons by sequestering toxic protofibrils and/or by consuming protein monomers, inhibiting continued protofibril formation (Caughey \& Lansbury, 2003). There is circumstantial evidence that fibrils may have a protective function. In PD brains, dopaminergic neurons that contain LBs appear to be 'healthier' than neighboring neurons based on morphological and biochemical criteria (Tompkins \& Hill, 1997). Several transgenic models of polyglutamine diseases are characterized 
by polyglutamine inclusions in healthy neuron populations, but not in vulnerable neurons (Kuemmerle et al. 1999). In a transgenic mouse model of one polyglutamine disease, spinocerebellar ataxia-type1 (SCA1), there was a direct correlation between the ability of neurons to sequester ataxin-1 into inclusions and their resistance to cell death (Watase et al. 2002). Taken together, these observations suggest that formation of fibrillar inclusions may protect neurons against protofibril-induced neurotoxicity. There is mounting evidence that the sequestration process may be an active one. Expression of any one of the four disease-associated proteins; cystic fibrosis transmembrane conductance regulator (CFTR, associated with cystic fibrosis) (Johnston et al. 1998), SOD1 (amyotrophic lateral sclerosis) (Johnston et al. 2000), the androgen receptor (AR, X-linked spinobulbar muscular atrophy) (Taylor et al. 2003), or Parkin (Junn et al. 2002) in cultured cells under conditions of oxidative stress or proteasome impairment leads to sequestration of the mutant protein within multicomponent proteinaceous inclusions known as aggresomes. Sequestration is actively mediated by microtubules (Johnston et al. 1998). In the case of Parkin, these inclusions exhibit morphological and immunohistochemical features similar to LBs (Junn et al. 2002). In addition to sequestering toxic protein aggregates, aggresomes may play an active role in facilitating the clearance of these toxic species by lysosomal mediated degradation mechanisms (Taylor et al. 2003).

\section{Amyloid pores, a common structural link among protein aggregation neurodegenerative diseases}

4.I Mechanistic studies of amyloid fibril formation reveal common features, including pore-like protofibrils

The convergent circumstantial evidence implicating protofibrils as pathogens has motivated a more detailed analysis of protofibril structure and formation in vitro. These studies are briefly summarized below and in Table 1, grouped according to the amyloid disease to which they are relevant. Similar pathways are followed by other fibrillogenic proteins that are not known to be related to disease (see Table 1 and below).

\section{I.I Amyloid- $\beta$ (A $\beta)$ (Alzheimer's disease)}

Alzheimer's disease (AD) is characterized by the presence of extracellular fibrillar amyloid plaques and intraneuronal neurofibrillary tangles in brain areas associated with memory and learning. The main fibrillar constituent of amyloid plaques is amyloid- $\beta$ ( $\beta$ (Glenner \& Wong, 1984), a 39-42 amino acid peptide that is produced by endoproteolytic processing of the APP (Selkoe, 1994). A central role for $\mathrm{A} \beta$ amyloid fibril formation in the etiology of AD is supported by extensive genetic and biochemical evidence (Hardy \& Selkoe, 2002). In solution, A $\beta$ is unstructured, but $\mathrm{A} \beta$ protofibrils, including spherical (average diameter of $2.4-4.5 \mathrm{~nm}$, containing $\sim 40$ monomers) and chain-like protofibrils and are rich in $\beta$-sheet structure (Fig. 1) (Harper et al. 1997a, b; Walsh et al. 1997; Lambert et al. 1998; Parbhu et al. 2002; Stine et al. 2003). Smaller oligomers (e.g. dimers, trimers and tetramers) likely exist, but are not populated in solution (they can only be observed by SDS-PAGE). Once the critical concentration of the spherical and later chain-like species is reached, they are rapidly converted into amyloid fibrils. In addition to the globular and chain-like protofibrils, annular structures with variable diameters (outer diameter 6-9 $\mathrm{nm}$, inner diameter 1.5-2 nm) have also been observed during the 
(a) $\mathrm{A} \beta$
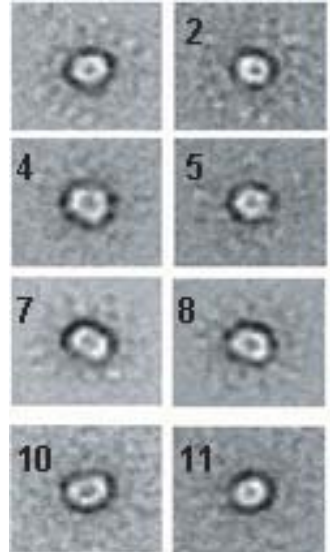

Arctic (E22G)

(b) A $\alpha$-Synuclein
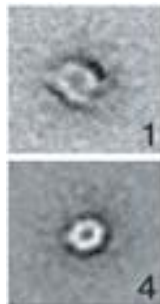

1
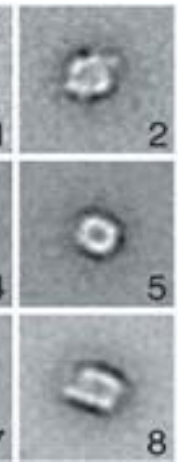

A53T

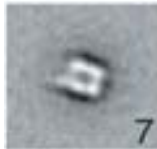

(e)

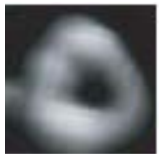

ABri
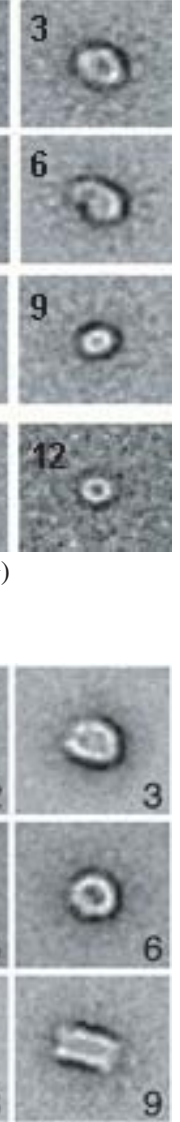

(d)
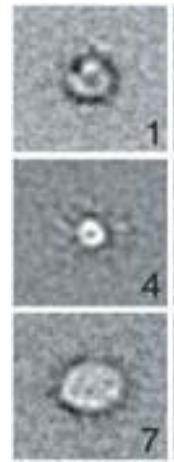

4

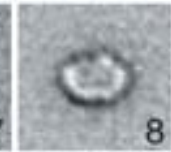

A30P

A4V
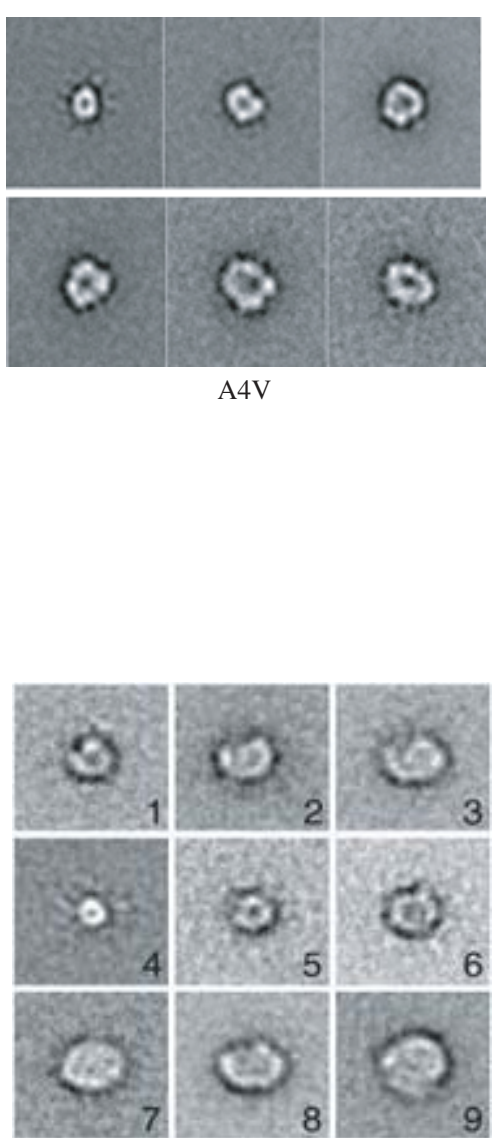

列

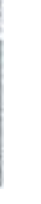


(a)

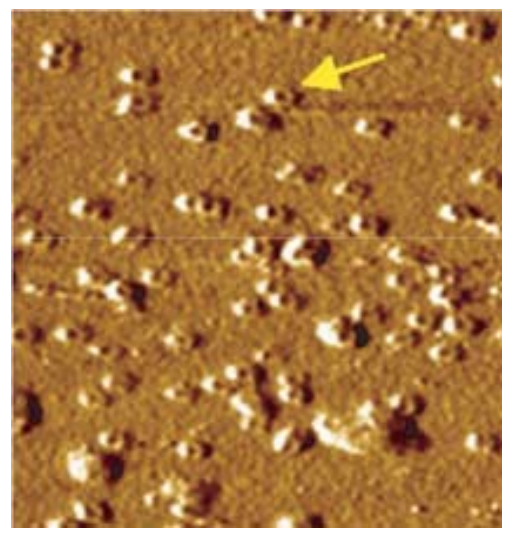

(b)

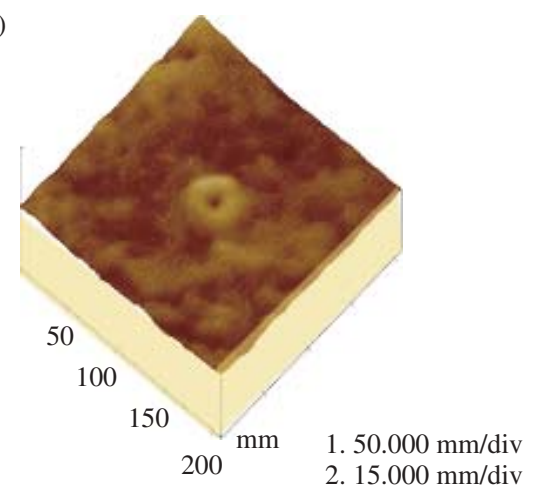

(c)

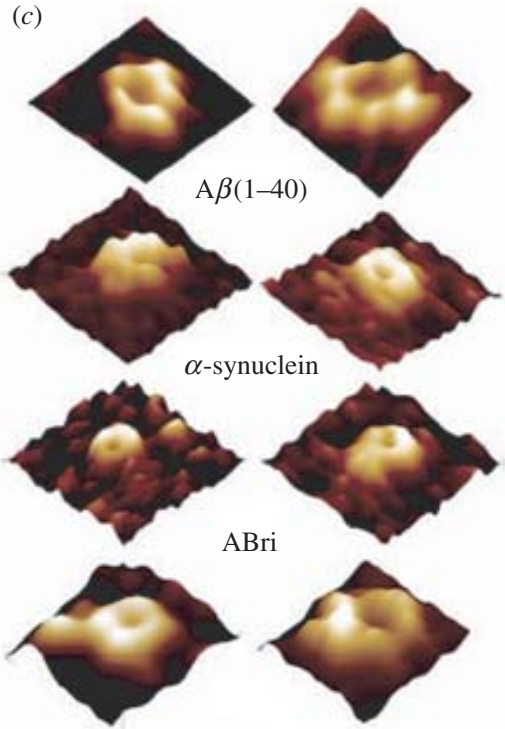

ADan

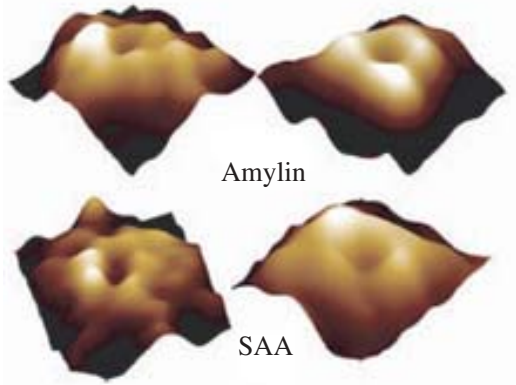

Fig. 3. Amyloid forming proteins form pore-like/channel structures on artificial as well as biological membranes. (a) AFM images of pore-like structures formed during the reconstitution of A $\beta$ in lipid bilayers (adapted from Lin et al. 2001). (b) Pore-like structures that were obtained by incubating predominantly spherical $\alpha$-synuclein protofibrils (WT and A53T) with brain-derived vesicles (adapted from Ding et al. 2002). (c) Amyloid-forming proteins/peptides reconstituted in lipid bilayers form pore/channel-like structures (adapted from Quist et al. 2005).

protofibrils at any given time, which explains why these structures were missed or ignored in previous studies.

\subsection{2 $\alpha$-Synuclein (PD and diffuse Lewy body disease)}

PD is associated with the formation of intraneuronal fibrillar inclusions (LBs) (Pollanen et al. 1993; Shults, 2006). $\alpha$-Synuclein is the primary component of LBs in all PD patients (Spillantini et al. 1998b) and is strongly implicated as a cause of PD by biochemical (Cookson, 2005) and genetic studies of familial forms of PD (Polymeropoulos et al. 1997; Kruger et al. 1998; Singleton et al. 2003; Zarranz et al. 2004) and by mouse (Masliah et al. 2000) and Drosophila (Feany \& Bender, 2000; Chen \& Feany, 2005) modeling studies. Three different $\alpha$-synuclein missense mutations (A30P, A53T and E46K) are associated with rare, autosomal dominant forms of earlyonset PD (Polymeropoulos et al. 1997; Kruger et al. 1998; Zarranz et al. 2004). In addition, triplication of the wild-type $\alpha$-synuclein gene causes autosomal dominant PD in an Iowan 
kindred (Singleton et al. 2003). Transgenic mice (Masliah et al. 2000) expressing human wild-type $\alpha$-synuclein and Drosophila (Feany \& Bender, 2000; Chen \& Feany, 2005) expressing W'T, A30P, or A53T are characterized by $\alpha$-synuclein non-fibrillar (mice and fly) or fibrillar (Flynn \& Theesen, 1999) inclusions and a Parkinsonian phenotype. Like A $\beta, \alpha$-synuclein is not folded under 'native' conditions (Weinreb et al. 1996), but will form $\beta$-sheet rich protofibrils and amyloid fibrils in vitro. Three mutations (A53T, E46K and A30P) linked to early-onset PD promote the formation of $\alpha$-synuclein protofibrils, but the A30P mutation was shown to form fibrils more slowly than WT $\alpha$-synuclein, suggesting that $\alpha$-synuclein protofibrils may cause neurodegeneration in PD (Conway et al. 1998; Conway et al. 2000; El-Agnaf et al. 1998; Li et al. 2001; Pandey et al. 2006). Amyloid fibril formation by $\alpha$-synuclein occurs by a hierarchical assembly mechanism (random coil $\rightarrow$ spheres $\rightarrow$ chain-like and annular protofibrils $\rightarrow$ fibrils) similar to that observed for $\mathrm{A} \beta$ in $\mathrm{AD}$ (Conway et al. 2000; Ding et al. 2002). The PD-linked mutations promote formation of annular and tubular protofibrillar structures (wild-type $\alpha$-synuclein forms annular protofibrils after extended incubation) (Conway et al. 2000; Ding et al. 2002; Lashuel et al. 2002a, b) (Fig. 2b,d). The diameter of $\alpha$-synuclein annular protofibrils detected in vitro is similar to that of the $\alpha$-synuclein fibrils. Zhu and colleagues observed the formation of $\alpha$-synuclein annular protofibrils during drug-induced disaggregation of $\alpha$-synuclein fibrils in vitro (Zhu et al. 2004), suggesting that a direct relationship between the two structures may exist. These observations are consistent with cross-sectional analysis of ex vivo amyloid fibrils demonstrating that amyloid fibrils have an electron-lucent center, indicative of the presence of a hollow center (Serpell et al. 2000).

\section{I.3 ABri (familial British dementia)}

ABri is the major component of amyloid deposits in the brain of patients with familial British dementia (FBD). FBD is an autosomal dominant neurodegenerative disorder associated with a stop codon mutation in the BRI gene that results in the production of ABri (Vidal et al. 1999; Ghiso et al. 2000). In vitro fibrillogenesis of ABri produced protofibrils and subsequently, amyloid fibrils (El-Agnaf et al. 2001a, b; Srinivasan et al. 2003, 2004), by a mechanism that is reminiscent of that of $\mathrm{A} \beta$ and $\alpha$-synuclein, including the formation of spherical, chain-like and annular protofibrillar intermediates. Spherical protofibrils exhibited more toxicity to cultured neurons than chain-like protofibrils and fibrils (El-Agnaf et al. 2001a). Annular ABri protofibrils have been characterized in vitro (see Fig. 2e) (Srinivasan et al. 2004; O. M. El-Agnaf, personal communication) but their toxicity has not been determined.

\section{I.4 Superoxide dismutase- I (amyotrophic lateral sclerosis)}

Amyotrophic lateral sclerosis (ALS), also known as Lou Gehrig's disease (Rosen, 1978; Julien, 2001), is linked to the gene encoding superoxide dismutase-type 1 (SOD1) (Rosen et al. 1993; Brown, 1997). Cytoplasmic inclusions containing mutant SOD1 are present in the motor neurons of familial ALS patients (Shibata et al. 1996) and transgenic mouse models (Bruijn et al. 1998; Watanabe et al. 2001). Significantly, these inclusions do not clearly contain fibrillar substructure. SOD1 is a structured homodimer. FALS mutations destabilize the native SOD1 dimer (Nakano et al. 1996; Cardoso et al. 2002b; Hayward et al. 2002; Lindberg et al. 2002; Rodriguez et al. 2002; Tiwari \& Hayward, 2003; Rakhit et al. 2004; Ray et al. 2004) and promote SOD1 aggregation in vitro (Ray et al. 2004). Significantly, SOD1 has not been induced to form amyloid 
fibrils in vitro. Instead, spherical and annular oligomeric structures have been observed (Chung, 2003; Ray et al. 2004). As expected, the pathogenic SOD1 mutants aggregate more rapidly than WT SOD1 (Chung, 2003; Ray et al. 2004), consistent with what is observed with $\mathrm{A} \beta$ and $\alpha$-synuclein (Lashuel et al. 2003; Lashuel et al. 2002a, b). Their findings suggest that common pathogenic assemblies may underlie all of these diseases. In addition to pathogenic mutations, conditions that promote metal depletion or oxidative damage of SOD1 accelerate the formation of annular structures by mutants and wild-type SOD (A4V, H46R, G37R, and G85R) (Chung, 2003; Elam et al. 2003; Ray et al. 2004). The morphology of these oligomeric forms of SOD1 formed in vitro resembles that of protofibrillar species of $\mathrm{A} \beta$ and $\alpha$-synuclein, in particular the annular and small spherical species (Fig. $2 c$ ). Thus, these species have been designated SOD1 protofibrils, yet they do not convert to fibrils over several weeks of incubation (Ray et al. 2004).

\section{I.5 Prion protein (Creutzfeldt-Jakob disease, bovine spongiform encephalopathy, etc.)}

The prion diseases [Creuzfeldt-Jakob disease (CJD), Gertsmann-Straussler syndrome (GSS), and fatal familial insomnia (FFI) in humans, bovine spongiform encephalopathy (BSE) in cattle, scrapie in sheep, and chronic wasting disease in elk] are characterized by the presence of an abnormal form of the PrP in the brain. The ability of these diseases to be transmitted, apparently by an abnormal form of the $\operatorname{PrP}$, distinguishes them from the others discussed here, but there are also sporadic forms of human prion disease as well as forms that are purely genetic; caused by mutations in the gene encoding $\operatorname{PrP}$ (CJD, GSS, and FFI). The disease-associated form of the $\operatorname{PrP}$, or PrP-Sc, is resistant to proteolysis and rich in $\beta$-sheet structure, relative to the normal form of the PrP, PrP-C (Cohen \& Prusiner, 1998). PrP-Sc can also be isolated in fibrous form (Rubenstein et al. 1987). However, several lines of evidence suggest that PrP-Sc, like other amyloid fibrils, may not be the neurotoxic form of the protein. Transgenic mice that overproduce a disease-associated form of PrP exhibit disease-like phenotypes before PrP-Sc can be detected (Chiesa \& Harris, 2001; Harris et al. 2003). During this phase, the protease-resistance of $\operatorname{PrP}$ gradually increased, suggesting the stepwise formation of structured oligomers of increasing stability. In vitro fibrillization of a fragment of $\operatorname{PrP}$ (residues 89-231) involves multiple oligomeric species, some of which appear to be off-pathway $\beta$-sheet-rich oligomers (Baskakov et al. 2002). Truncated variants of $\mathrm{PrP}$ form spherical and elongated protofibril-like structures that share properties with $\mathrm{PrP}-\mathrm{Sc}$ and are capable of seeding the conversion of $\mathrm{PrP}^{\mathrm{C}}$ into amyloid fibrils (Lee \& Eisenberg, 2003). Finally, a truncated variant of $\operatorname{PrP}(\mathrm{SHaPrP} 90-232)$ forms spherical and annular oligomeric structures in vitro, similar to those formed by $\mathrm{A} \beta$ and $\alpha$-synuclein (Sokolowski et al. 2003). It was estimated that 8 subunits of $\mathrm{SHaPrP} 90-232$ are required to form the $\beta$-sheet-rich annular structures (Sokolowski et al. 2003).

\subsubsection{Huntingtin (Huntington's disease)}

Huntington's disease is the most prevalent of a group of purely genetic neurodegenerative movement disorders that are caused by expansions of naturally occurring polyglutamine (polyQ) tracts in several proteins (the normal function of these tracts is not known) (Zoghbi \& Orr, 2000). The magnitude of the expansion is related to the age of onset of the disease, with large expansions causing juvenile onset disease. The Huntington's disease brain is characterized by nuclear inclusions comprising the protein huntingtin (htn). Truncated mutant versions of htn with expanded polyQ repeat form spherical (Poirier et al. 2002; Wacker et al. 2004) chain-like 
(Poirier et al. 2002), and annular (Wacker et al. 2004) protofibrillar structures in vitro that closely resemble those discussed above.

\subsection{Amyloidogenic proteins that are not linked to disease also from pore-like protofibrils}

Several other proteins that are not associated with disease form annular protofibrillar structures during the in vitro formation of amyloid fibrils. Conditions required to induce annular protofibrils vary depending on the precursor protein. Under partial denaturing conditions, the calciumbinding protein equine lysozyme (EL) self-assembles into protofibrils and fibrils of various morphologies in a $\mathrm{pH}$ and calcium dependent manner (Malisauskas et al. 2003). At pH 4.5 and $57^{\circ}$ in the presence of $10 \mathrm{~mm}$ EDTA, EL forms annular structures with an average diameter of $45 \mathrm{~nm}( \pm 5 \mathrm{~nm})$, whereas at $\mathrm{pH} 2.0 \mathrm{EL}$ forms rings with larger diameters ranging from $70-80 \mathrm{~nm}$. Interestingly, in the presence of calcium at $\mathrm{pH} 4 \cdot 5$, elongated chain like structure are populated as the major species, but upon removal of calcium, EL forms predominantly annular structures (major species by AFM). Similarly, partial denaturing conditions were sufficient to induce oligomerization and formation of pore-like structures by the core domain of the tumor suppressor protein p53C (Ishimaru et al. 2003). Furthermore, Glabe \& Kayed reported to have developed conditions for the formation of highly homogeneous preparations of annular protofibrils (outer diameter 8-12 nm, inner diameter 1.8-4.5 nm) from several amyloidogenic proteins, including A $\beta, \alpha$-synuclein, IAPP, polyglutamine (KKQ40KK), Prion H1 (106-126), TTR and several $\mathrm{A} \beta$ variants (Kayed \& Glabe, 2004). It has been proposed that the ability of a wide range of proteins to form annular protofibrils suggest that these quaternary structures might represent a second generic form of amyloid structures in addition to amyloid fibrils (Malisauskas et al. 2003). Furthermore, the ability to populate pore-like structures as the predominant species in vitro by manipulating solution conditions, suggest that in vivo conditions that promote the formation of these structure could exist.

\subsection{Amyloid proteins form non-fibrillar aggregates that have properties of protein channels or pores}

Disruption of $\mathrm{Ca}^{2+}$ homeostasis and generation of reactive oxygen species have long been recognized to be key events in the pathogenesis of several neurodegenerative diseases, including AD (Hardy \& Higgins, 1992). Cellular factors responsible for initiating these events and the mechanism by which they contribute to the neurodegeneration and cytotoxicity remain poorly understood.

Every protein that forms amyloid fibrils in vitro does so via the protofibril. Aggregates comprising many of these proteins have channel-like or pore-like properties in vitro (the most relevant studies are summarized below). We propose that the pore-like properties arise from the pore-like protofibrillar structures or the ability of a protofibrillar intermediate to form these structures upon interactions with membranes. We prefer the term pore as opposed to channel, because the latter implies selectivity and regulation and we do not expect that either is involved with amyloid associated diseases. However, the terms used in the sections below reflect literature usage.

\subsection{A $\beta$ 'channels'}

In 1993, Arispe and colleagues demonstrated that $\mathrm{A} \beta$ forms calcium channels in lipid bilayers and proposed that channel formation by $\mathrm{A} \beta$ is partially or wholly responsible for $\mathrm{A} \beta$-induced 
toxicity in AD (Arispe et al. 1993a, b). This finding has been reproduced many times, in several different laboratories, using many membrane models (Arispe et al. 1993b, 1994; Kawahara et al. 1997, 2000; Sanderson et al. 1997; Rhee et al. 1998; Hirakura et al. 1999; Lin et al. 1999, 2001; Bhatia et al. 2000; Kourie et al. 2001b; Kagan et al. 2002; Lin \& Kagan, 2002; Bahadi et al. 2003a; Alarcon et al. 2006). The form of $\mathrm{A} \beta$ that is closely linked to $\mathrm{AD}$ pathogenesis (A $\beta 42)$ exhibits higher propensity to form channels, consistent with its increased propensity to aggregate and form annular protofibrils in vitro (H. Lashuel \& P. T. Lansbury Jr., unpublished observations) as compared to $\mathrm{A} \beta 40$, the predominant form (Jarrett et al. 1993). $\beta$-sheet formation is also linked to $\mathrm{A} \beta$-channel formation (and aggregation) (Sanderson et al. 1997). When incorporated into artificial lipid bilayers, $\mathrm{A} \beta$ produces uniform pore-like structures with an outer diameter of $8-12 \mathrm{~nm}$ and inner diameter of $2 \mathrm{~nm}$ (Fig. 3a,c) (Lin et al. 2001; Quist et al. 2005). These aggregates, formed at the membrane surface, resemble, pore-like aggregates formed in solution using $\mathrm{A} \beta 42$ or the disease-associated mutant form of $\mathrm{A} \beta 40$ (E22G) (Lashuel et al. 2002b, 2003). Addition of A $\beta 40$ oligomers to hypothalamic GT1-7 neuronal cells results in simultaneous formation of $\mathrm{Ca}^{2+}$ channels and increase in intracellular $\mathrm{Ca}^{2+}$ levels, suggesting that $\mathrm{A} \beta 40$ oligomers is capable of disrupting biological as well as artificial membranes, possibly via pore formation (Kawahara \& Kuroda, 2001, 2000; Singer \& Dewji, 2006). The nature of the oligomer responsible for this activity was not investigated. $\mathrm{AD}$-derived $\mathrm{A} \beta$ oligomers were observed to exhibit high affinity and selective attachment to membranes, suggesting that AD-derived oligomers are either directly integrated into the membranes or bind tightly to other cell surface molecules of cultured hippocampal neurons (Gong et al. 2003). Oligomer-specific antibodies were shown to block their interaction with membranes.

\subsection{2 $\alpha$-Synuclein 'pores'}

The $\alpha$-synuclein protofibril (but not the monomer or the fibril) binds very strongly to vesicle membranes and causes leakage of small compounds (less than $\sim 2.5 \mathrm{~nm}$ hydrodynamic radius) entrapped within synthetic vesicles (Volles et al. 2001; Volles \& Lansbury, 2002). This typical pore-like behavior was consistent with the observation that addition of spherical protofibrils of $\alpha$-synuclein to purified brain-derived vesicle (BDV) fractions resulted in the formation of porelike structures (Fig. 3b) (Ding et al. 2002). Additionally, reconstitution of a-synuclein in lipid bilayers also results in the formation of pore-like structures that exhibit channel-like properties (Quist et al. 2005). Mutations linked to familial PD promoted the formation of the $\beta$-sheet-rich annular, pore-like ( $d=8-12 \mathrm{~nm}, 2-2 \cdot 5 \mathrm{~nm}$ inner diameter) structures in solution (Lashuel et al. 2002a, b). These structures resembled in morphology and dimension, membrane-spanning pores that are formed by protein toxins (e.g. hemolysin, latrotoxin, and aerolysin) (Valeva et al. 1997; Orlova et al. 2000; Wallace et al. 2000). Vesicle permeabilization was also demonstrated for protofibrils comprising the congener $\gamma$-synuclein, but not those comprising $\beta$-synuclein (Park \& Lansbury, 2003). At the same time, $\gamma$-synuclein, but not $\beta$-synuclein, produced pore-like structures in solution (H. Lashuel, unpublished results), strengthening the case that the pore-like structures are responsible for the pore-like behavior of $\alpha$-synuclein.

\subsubsection{PrP 'channels'}

Aguzzi and colleagues have proposed that the pathogenicity of the PrP may be related to abnormal pore formation (Moore et al. 1999; Rossi et al. 2001; Behrens \& Aguzzi, 2002). This proposal, based on studies of a PrP homolog, Doppel, is supported by circumstantial 
experimental evidence. First, an abnormal transmembrane (translocation-incompetent) form of PrP has been linked to disease (Hegde et al. 1999). Second, a peptide based on the proposed transmembrane domain of PrP produce non-fibrillar aggregates that disrupt membranes (Pillot et al. 1997) and induce toxicity in rat cortical neurons (Pillot et al. 2000). Third, several PrP-based peptides interacts with lipid membranes and form ion channels (Lin et al. 1997; Kourie \& Culverson, 2000; Bahadi et al. 2003b, c). Fourth, a truncated form of PrP permeabilizes synthetic vesicles (Sanghera \& Pinheiro, 2002). Fifth, when disease-associated mutant forms of PrP were expressed in $\mathrm{CHO}$ cells, $\mathrm{PrP}$ was found to be very tightly associated with plasma membranes (Lehmann \& Harris, 1996).

\subsubsection{Polyglutamine 'channels'}

Peptides with pathological polyglutamine repeats ( $>35-40$ residues) insert into artificial membranes (Hirakura et al. 2000a; Monoi et al. 2000; Kagan et al. 2001) and also affect mitochondrial $\mathrm{Ca}^{2+}$ homeostasis (Panov et al. 2002). Furthermore a polyglutamine (Gln40) peptide produced homogeneous pore-like protofibrillar structures in vitro, while a shortened peptide did not (Monoi et al. 2000). Importantly, $\beta$-sheet formation, oligomerization, amyloid pore/channel formation, and fibrillogenesis are also very sensitive to polyGln repeat length (Scherzinger et al. 1999). Circumstantial evidence suggests that membrane disruption is mediated by direct interaction between the polyglutamine repeats or an aggregated form of these proteins resulting in the formation of ion channels in lipid bilayers and in mitochondrial membranes. Interestingly, only pathological polyglutamine repeat $(>35-40)$ were observed to insert into artificial membranes and exhibited direct effects on mitochondrial $\mathrm{Ca}^{2+}$ homeostasis, reproducing the mitochondrial deficit seen in Huntington's disease patients and in transgenic animals expressing these repeats (Hirakura et al. 2000a; Monoi et al. 2000; Kagan et al. 2001; Panov et al. 2002). Furthermore, Kayed \& Glabe (2004) reported that a polyglutamine protein containing 40 repeat (KKQ40KK) forms homogeneous annular pore-like protofibrillar structures in vitro, suggesting that protofibril formation and channel activity are linked.

Monoi and colleagues proposed that a single chain of poly-glutamine polypeptide is capable of forming cylindrical pores by forming a right handed helix ( $6 \cdot 2$ residues/turn), termed $\mu$-helix, that is further stabilized by backbone side-chain hydrogen bonding interactions between the amide groups and glutmaine side-chain (Monoi, 1995; Monoi et al. 2000). What makes this model an attractive one is that it offers an explanation for the requirement of $>35$ polyglutamine tract to confer pathogenecity in polyglutamine diseases, because 37 residues (each contributing $0 \cdot 81 \AA$ to the length) would be required to form a $\mu$-helix that spans the hydrophobic region of the bilayer $(30 \AA)$. A normal transmembrane domain composed of an $\alpha$-helix is $\sim 20$ amino acids long. However, $\beta$-sheet formation, oligomerization and fibrillogenesis by poly-glutamine proteins are highly dependent on the polyQ repeat length with 36 or more glutamines favoring these tertiary and quaternary structure changes (Scherzinger et al. 1999). However, further studies are required to elucidate the nature of the membrane active species responsible for polyglutamine membrane disruption properties.

\subsection{Nature uses $\beta$-strand-mediated protein oligomerization to construct pore-forming toxins}

A simple working hypothesis emerging from the studies summarized above holds that five properties of disease-associated amyloid proteins are linked: (1) aggregation, (2) $\beta$-sheet formation, 


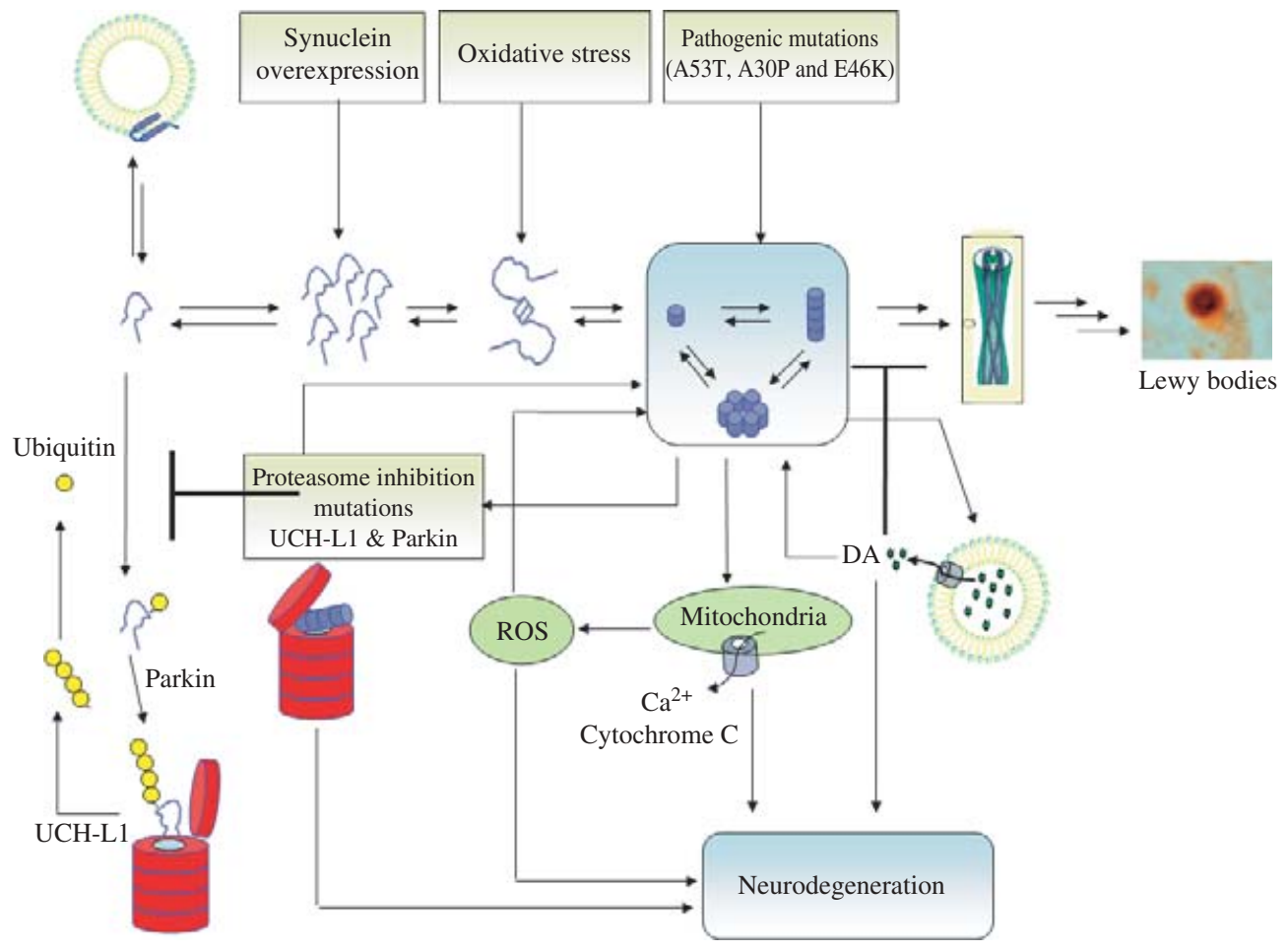

Fig. 4. Schematic depiction of the various steps involved in $\alpha$-synuclein aggregation and Lewy Body formation and potential mechanisms by which these processes could contribute to the pathogenesis of PD. Several factors have been shown to play a role in initiating and/or accelerating $\alpha$-synuclein aggregation and fibrillogenesis including, increased protein expression, mutations, oxidative stress induced modifications and crosslinking, and phosphorylation at S129 (Chen \& Feany, 2005; Fujiwara et al. 2002; Smith et al. 2005). The scheme depicts amyloid protofibril as the toxic species and that it may amplify itself by inhibiting proteasome-dependent protein degradation, disrupting dompaniergic vesicles, formation of reactive oxygen species and increased oxidative stress, causing mitochondrial dysfunction (Abou-Sleiman et al. 2006), all of which have the affect of increasing levels of $\alpha$-synuclein and/or accelerating $\alpha$-synuclien oligomerization and protofibril formation. This hypothesis is supported by the findings that triplication of the $\alpha$-synuclein gene causes and autosomal dominant PD in Iowan kindred (Singleton et al. 2003). Protofibrils may promote their own accumulation and toxicity by inhibiting the proteasome. Two gene products in the protein degradation pathway have been implicated in early onset forms of PD (Lansbury \& Brice, 2002). One form is associated with genetic mutations in the gene encoding parkin (a protein with an E3 (ubiquitin ligase)-like activity), where the mutations reduce or abolish parkin's E3-like ligase activity (Kitada et al. 1998). A rare point mutation in the gene encoding ubiquitin C-terminal hydrolase (UCH-L1), a neuronal-specific deubiquitinating enzyme, is thought to lead to reduced catalytic activity of UCH-L1, and, thus, indirectly affect the proteasomal function (Leroy et al. 1998). Furthermore, reduced expression of UCH-L1 in the substantia nigra of DLB and PD brains suggest that it plays a role in modulating protein ag gregation and LB formation (Barrachina et al. 2005). In addition to its beneficial hydrolase activity (hydrolysis of C-terminal ubiquityl esters and amides), UCH-L1 exhibits a concentration dependent ubiquityl ligase activity that is thought to be pathogenic for PD. Taking together, these findings demonstrate that accumulation of $\alpha$-synuclein either due to increased expression or decreased degradation is sufficient to cause PD, as predicted by the amyloid hypothesis.

(3) amyloid pore formation, (4) membrane permeabilization, and (5) toxicity (see Fig. 4). This proposal is more compelling because natural protein toxins utilize an analogous mechanism. Latrotoxin, $\alpha$-hemolysin, and aerolysin all form well-ordered, oligomeric membrane-spanning pores characterized by $\beta$-sheet structure. It is important to remember that while these toxins are 
optimized by evolution to permeabilize target membranes, amyloid pore formation is likely to be an accident and will therefore be very inefficient in vitro. Pore formation by $\beta$-sheet bacterial toxins involves a series of complex events that include membrane association, oligomerization, and insertion of a $\beta$-barrel. The pore-forming protein toxins (PFTs) typically exist as structured, water-soluble monomers; conversion into the membrane-inserted pore requires that these proteins undergo oligomerization and a conformational change. In the case of aerolysin, proteolytic processing by the target is required to initiate the formation of the transmembrane $\beta$-barrel domain (Abrami et al. 1998). The PFT proteins typically aggregate and/or are activated (Walker et al. 1992; Song et al. 1996; Sellman et al. 1997; Heuck et al. 2003) at the membrane surface, a feature that promotes membrane selectivity. Up to $100 \beta$-hairpins can be inserted on activation, to produce the transmembrane $\beta$-sheet pore (Hotze et al. 2001). $\beta$-barrels that span the membrane (Valeva et al. 1997; Heuck et al. 2001) typically comprise 8-22 $\beta$-strands (each 1013 residues long) and have an average diameter of 1.5-3.5 nm (Heuck et al. 2001, 2003). In the $\alpha$-hemolysin barrel, each monomer contributes an amphipathic hairpin to a 14-stranded heptameric $\beta$-barrel (Menestrina et al. 2001). PFTs form pores ranging in diameter from 1 to $2 \mathrm{~nm}$ for staphylococcal $\alpha$-hemolysin (Fussle et al. 1981) and Vibrio cholerae cytolysin (Zitzer et al. 1995), and from 15 to $45 \mathrm{~nm}$ for streptolysin O (Sekiya et al. 1993) and perfringolysin O (Olofsson et al. 1993). For some PFTs, some degree of heterogeneity (pore size and oligomeric state) has been reported (Sharpe \& London, 1999; Tadjibaeva et al. 2000). PFT membrane binding and oligomerization are dependent on the membrane composition and microenvironment and, in some cases, are mediated by interaction with receptor molecules. Cholesterol, for example, can play a critical role in PFT insertion (Cabiaux et al. 1997), and may also play a role in amyloid pore toxicity (Arispe \& Doh, 2002; Curtain et al. 2003; Eckert et al. 2003).

\section{Mechanisms of protofibril induced toxicity in protein aggregation diseases}

5.I The amyloid pore can explain the age-association and cell-type selectivity of the neurodegenerative diseases

Most cases of AD, PD and ALS are sporadic, that is, they do not involve mutant protein, and are strongly age-associated. Any model for pathogenesis must explain these cases. It is important to emphasize that the wild-type proteins will also form amyloid pores in vitro, albeit more reluctantly than the disease-associated mutants (Hafner et al. 2001; Ding et al. 2002; Lashuel et al. 2002a, b, 2003; Shtilerman et al. 2002; Chromy et al. 2003; Chung, 2003; Klug et al. 2003; Kayed \& Glabe, 2004). Factors other than mutations could trigger pore formation pathogenesis in sporadic disease (Fig. 4). These factors could include (but are not limited to): (1) increased expression of the amyloid-forming protein (Singleton et al. 2004; Uryu et al. 2003); (2) impaired degradation of the monomeric protein by the proteasome (Giasson \& Lee, 2003); (3) impaired degradation of the protofibrils by a lysosome-mediated autophagic process (Lee et al. 2004); (4) changes in chaperone activity and/or expression of homologs that act as specific chaperones (Rochet $e t a l$. 2000; Conway et al. 2001; Hashimoto et al. 2001; Masliah \& Hashimoto, 2002); (5) changes in levels of post-translational modification, both enzymatic (Shimura et al. 2001; Fujiwara et al. 2002; Chen \& Feany, 2005; Smith et al. 2005) and non-enzymatic (Conway et al. 2001); (6) changes in the pathogenic microenvironment $(\mathrm{pH}$, membrane composition, increased oxidation). Oxidative damage of amyloid-forming proteins increases their propensity to misfold and aggregate in vitro (Rakhit et al. 2002; Dauer \& Przedborski, 2003). Expression of $\alpha$-synuclein in 
cells, under oxidizing conditions, promotes cytoplasmic aggregation and cell death (Kim et al. 2003; Smith et al. 2005). Many of the factors listed above are ATP-dependent and would therefore be expected to emerge on aging (Heydari et al. 1995; Gaczynska et al. 2001; Soti \& Csermely, 2002; Ferrington et al. 2005; Chondrogianni, 2005), when ATP production becomes less efficient. Aging may also affect the susceptibility of membranes to permeabilization; age-dependent changes in the distribution of cholesterol in neuronal membranes can facilitate oligomerization and accumulation of $\mathrm{A} \beta$ in plasma membranes (Wood et al. 2002) and cholesterol content influences $\mathrm{A} \beta$ toxicity in cell culture (Arispe \& Doh, 2002). It must be emphasized that of the factors listed above, all except membrane composition can be easily rationalized by other pathogenic mechanisms.

Another striking feature of the neurodegenerative diseases is that they are selective for certain neuronal populations (hence the clinical diversity). This feature can be explained by an amyloid pore model. It is likely that structural differences among protofibrils formed by the various amyloid-forming proteins would confer some specificity in the way they interact with cellular membranes. In addition, accessory molecules could play a role in modulating pore formation. Finally, conversion of annular protofibrils into amyloid pores may occur at the membrane surface in vivo, triggered by specific environmental factors, changes in fluidity of the membrane or interaction with specific proteins. For example, the selective vulnerability of dopaminergic neurons of the substantia nigra to $\alpha$-synuclein toxicity in PD may be related to (1) the relatively low expression of $\beta$-synuclein (Rockenstein et al. 2001), a homolog that prevents $\alpha$-synuclein protofibril formation in vitro (Park \& Lansbury, 2003), (2) the high concentration of cytoplasmic dopamine (Lotharius \& Brundin, 2002; Xu et al. 2002) in these cells (some populations of dopaminergic neurons, that have more efficient machinery for removal of cytoplasmic dopamine, are resistant to PD), or (3) highly oxidizing conditions (higher levels of free radical scavengers are expressed in PD-resistant populations of dopaminergic neurons) (Hirsch et al. 1997), A combination of the latter two factors may generate dopamine ortho-quinone, which, in vitro, covalently modifies $\alpha$-synuclein and stabilizes protofibrils (Conway et al. 2001; Li et al. 2004). The extreme sensitivity of dopaminergic neurons to proteasomal inhibition (McNaught et al. 2002) may be related to the importance of keeping cytoplasmic $\alpha$-synuclein levels low in these cells. Second, the differences between cell-types would be expected to influence the specific activity of the amyloid pores in a way that depended on the protein constituent. Microinjection of protofibrillar A $\beta 42$ induces death of human neurons, but not neuroblastoma cells, astrocytes or other non-neuronal cell lines (Zhang et al. 2002). Decreased susceptibility to intracellular toxicity could arise from the absence of 'receptor' molecules that mediate $\mathrm{A} \beta$ toxicity, the presence of neuroprotective factors, or just the changed composition of target membranes.

\subsection{Protofibrils may promote their own accumulation by inhibiting the proteasome}

Neurons have developed housekeeping systems to avoid misfolded proteins accumulating in the cytoplasm. These include the chaperone system [some of which is ATP-dependent and would be compromised on aging (Heydari et al. 1995; Soti \& Csermely, 2002)], which prevents aggregation (Muchowski, 2002; McClellan et al. 2005) and the proteasomal system, which degrades misfolded and damaged proteins (Berke \& Paulson, 2003; Ross \& Pickart, 2004). The importance of ubiquitin-dependent proteasomal degradation in PD is illustrated by the fact that parkin and UCH-L1, two PD-linked gene products, are involved in this process (Lansbury \& Brice, 2002) (Fig. 4). Once protein aggregation has occurred, several backup systems may take over, including 
the HSP90 heat-shock protein, that is capable of disaggregating these species (Ben-Zvi \& Goloubinoff, 2001; Ben-Zvi et al. 2004), the autophagy system, which engulfs and degrades protein aggregates [including protofibrils (Lee et al. 2004)] via fusion with the lysosome, and the 'aggresome' system (Kopito, 2000). Complete or partial failure of any of these systems could have detrimental consequences for the cell. Convergent evidence indicates that the protofibrils themselves could compromise proteasomal degradation. First, overexpression of diseaseassociated proteins (SOD1 or $\alpha$-synuclein) in non-neuronal cells resulted in inhibition of proteasome activity (Tanaka et al. 2001; Urushitani et al. 2002). Second, aggregated (protofibrillar and fibrillar) $\alpha$-synuclein binds directly to the proteasome and inhibits proteasomal activity (Snyder et al. 2003; Lindersson et al. 2004). Third, inhibition of the neuronal proteasome causes cytosolic inclusion formation (Ma \& Lindquist, 2002) and neuronal death (Ma et al. 2002). It is not known whether neuronal death is a result of an increase in protein aggregation due to decreased degradation or of another proteasome-mediated event (Bennett et al. 2005). The former scenario offers a mechanism whereby toxicity can amplify itself.

\section{Testing the amyloid pore hypothesis by attempting to disprove it}

In the past 4 years, 18 different amyloid-forming proteins have been reported to form prefibrillar intermediates with pore-like morphologies (Table 1), supporting the notion that formation of the pore and formation of the fibril are tightly linked. However, whether the pore has any relevance to disease, as proposed here, is not at all clear. It must be emphasized that there is a much work to be done to strengthen the case, which must, by definition, be based on circumstantial evidence. A goal of this review is to encourage experiments designed to disprove the hypothesis. In closing, we make three points, each based on different experimental approaches:

(1) Detection of amyloid pores in tissue from patients or animal models does not support the bypothesis nor does the failure to detect these structures disprove it. This point is illustrated by the flawed logic that led to the toxic fibril hypothesis. However, one could argue that, in the absence of evidence for the existence of pores in tissue, there is no proof that they are able to form under physiological conditions. Several studies of $\alpha$-synuclein aggregates extracted from brains affected by rare neurodegenerative diseases related to PD, provide tantalizing evidence that pore-like structures do exist in vivo. Several studies of $\alpha$-synuclein fibrils from diffuse Lewy body disease (DLBD) reveal pore-like structures that co-purify with $\alpha$-synuclein fibrils (Spillantini et al. 1998a; Fujiwara et al. 2002). The resemblance of these structures to the amyloid pores produced from $\alpha$-synuclein in vitro (Lashuel et al. 2002a) is striking. Direct evidence for the existence of amyloid pore-like structures in vivo has been provided by the extraction of annular $\alpha$-synuclein structures, similar to those seen in in vitro preparations, from inclusions from post-mortem brain tissues of a multiple system atrophy (MSA, another $\alpha$-synuclein aggregation disease) patient (Pountney et al. 2004).

(2) Evidence for membrane abnormalities is consistent with the amyloid pore, but these abnormalities could easily have arisen by another mechanism. Formation of unregulated pores at the mitochondrial membrane could result in altered $\mathrm{Ca}^{2+}$ homeostasis, the release of cytochrome $c$ and other proapoptotic molecules, ultimately causing increased oxidative stress and apoptosis. These are features that are clearly seen in the motor neurons of the post-mortem ALS brain, where mitochondrial swelling and cytochrome $c$ release are invariant features (Menzies et al. 2002). In cellular models of PD, Golgi fragmentation, which is a common feature of human 
neurodegenerative diseases, including PD, AD, ALS, CJD, is specifically linked to protofibril formation (Gosavi et al. 2002).

(3) Determination of the toxicity of a mutant protein that efficiently forms very stable pores would be very informative. According to the amyloid pore hypothesis, mutations in amyloid proteins that stabilized pores to a great extent may have been disfavored by natural selection, since they would have led to juvenile-onset disease. If one could discover a mutation that had this effect in vitro, one could then determine its toxicity relative to disease-linked mutants in cellular and/or animal models of disease. If such a mutant lacked in vivo toxicity, then the amyloid pore hypothesis would be untenable. If such a mutant was extremely toxic, the circumstantial case would be considerably stronger. We are working hard to find such a mutant. Hopefully, the identification of the pathogenic species will motivate drug discovery efforts aimed at treating the neurodegenerative processes that underlie these devastating diseases.

\section{Acknowledgments}

We thank members of the Lansbury and Walz laboratories for their contribution to this field and for thoughtful discussions on the subject, Mr Asad Qureshi for reviewing the manuscript and assistance with the references, and Dr Michael Zagorski for providing the protofibril images of ABri.

\section{References}

Abou-Sleiman, P. M., Muqit, M. M. \& Wood, N. W. (2006). Expanding insights of mitochondrial dysfunction in Parkinson's disease. Nature Reviews Neuroscience 7, 207-219.

Abrami, L., Fivaz, M., Decroly, E., Seidah, N. G., Jean, F., Thomas, G., Leppla, S. H., Buckley, J. T. \& Van Der Goot, F. G. (1998). The pore-forming toxin proaerolysin is activated by furin. Journal of Biological Chemistry 273, 32656-32661.

Aksenova, M. V., Aksenov, M. Y., Butterfield, D. A. \& CARNEY, J. M. (1996). alpha-1-antichymotrypsin interaction with A beta (1-40) inhibits fibril formation but does not affect the peptide toxicity. Neuroscience Letters 211, 45-48.

Alarcon, J. M., Brito, J. A., Hermosilla, T., Atwater, I., Mears, D. \& Rojas, E. (2006). Ion channel formation by Alzheimer's disease amyloid beta-peptide (Abeta40) in unilamellar liposomes is determined by anionic phospholipids. Peptides 27, 95-104.

Anguiano, M., Nowak, R. J. \& Lansbury Jr., P. T. (2002). Protofibrillar islet amyloid polypeptide permeabilizes synthetic vesicles by a pore-like mechanism that may be relevant to type II diabetes. Biochemistry 41, 11338-11343.

Arispe, N. \& Doh, M. (2002). Plasma membrane cholesterol controls the cytotoxicity of Alzheimer's disease AbetaP (1-40) and (1-42) Peptides. Faseb Journal 16, 1526-1536.
Arispe, N., Pollard, H. B. \& Rojas, E. (1993a). Giant multilevel cation channels formed by Alzheimer disease amyloid beta-protein [A beta P-(1-40)] in bilayer membranes. Proceedings of the National Academy of Sciences USA 90, 10573-10577.

Arispe, N., Pollard, H. B. \& Rojas, E. (1994). betaAmyloid $\mathrm{Ca}\left({ }^{2+}\right)$-channel hypothesis for neuronal death in Alzheimer disease. Molecular and Cellular Biochemistry 140, 119-125.

Arispe, N., Pollard, H. B. \& Rojas, E. (1996). $\mathrm{Zn}^{2+}$ interaction with Alzheimer amyloid beta protein calcium channels. Proceedings of the National Academy of Sciences USA 93, 1710-1715.

Arispe, N., Rojas, E. \& Pollard, H. B. (1993b). Alzheimer disease amyloid beta protein forms calcium channels in bilayer membranes: blockade by tromethamine and aluminum. Proceedings of the National Academy of Sciences USA 90, 567-571.

Azimov, R., Azimova, R., Hirakura, Y. \& Kagan, B. L. (2001). Ion channels of different selectivity formed by transthyretin. Biophysical Journal 80, 129a.

Bahadi, R., Farrelly, P. V., Kenna, B. L., Curtain, C. C., Masters, C. L., Cappai, R., Barnham, K. J. \& Kourie, J. I. (2003a). $\mathrm{Cu}^{2+}$-induced modification of the kinetics of $\mathrm{A} \beta[[\mathrm{LB}]] 1-42[[\mathrm{RB}]]$ channels. American Journal of Physiology - Cell Physiology 285, C873-C880.

Bahadi, R., Farrelly, P. V., Kenna, B. L., Kourie, J. I., Tagliavini, F., Forloni, G. \& Salmona, M. (2003b). 
Channels formed with a mutant prion protein $\operatorname{PrP}$ (82-146) homologous to a $7-\mathrm{kDa}$ fragment in diseased brain of GSS patients. American Journal of Physiology - Cell Physiology 285, C862-872.

Bahadi, R., Farrelly, P. V., Kenna, B. L., Kourie, J. I., Tagliavini, F., Forloni, G. \& Salmona, M. (2003c). Ion channels formed with a synthetic mutant prion protein ( $\operatorname{PrP}[[\mathrm{LB}]] 82-146[[\mathrm{RB}]])$ homologous to a $7 \mathrm{kDa}$ fragment found in the diseased brain of Gerstmann-Straussler-Scheinker syndrome. American Journal of Physiology - Cell Physiology 285, C862-C872.

Barghorn, S., Nimmrich, V., Striebinger, A., Krantz, C., Keller, P., Janson, B., Bahr, M., Schmidt, M., Bitner, R. S., Harlan, J., Barlow, E., Ebert, U. \& Hillen, H. (2005). Globular amyloid beta-peptide oligomer-a homogenous and stable neuropathological protein in Alzheimer's disease. Journal of Neurochemistry 95, 834-847.

Barrachina, M., Castano, E., Dalfo, E., Maes, T., Buesa, C. \& Ferrer, I. (2005). Reduced ubiquitin Cterminal hydrolase-1 expression levels in dementia with Lewy bodies. Neurobiology of Disease Journal 22, 265-273.

Baskakov, I. V., Aagaard, C., Mehlhorn, I., Wille, H., Groth, D., Baldwin, M. A., Prusiner, S. B. \& Cohen, F. E. (2000). Self-assembly of recombinant prion protein of 106 residues. Biochemistry 39, 2792-2804.

Baskakov, I. V., Legname, G., Baldwin, M. A., Prusiner, S. B. \& Cohen, F. E. (2002). Pathway complexity of prion protein assembly into amyloid. Journal of Biological Chemistry 277, 21140-21148.

Behrens, A. \& Aguzzi, A. (2002). Small is not beautiful: antagonizing functions for the prion protein $\operatorname{Pr} \mathrm{P}(\mathrm{C})$ and its homologue Dpl. Trends in Neurosciences 25, 150-154.

Ben-Zvi, A., De los Rios, P., Dietler, G. \& Goloubinoff, P. (2004). Active solubilization and refolding of stable protein aggregates by cooperative unfolding action of individual hsp 70 chaperones. Journal of Biological Chemistry 279, 37298-37303.

Ben-Zvi, A. P. \& Goloubinoff, P. (2001). Review: mechanisms of disaggregation and refolding of stable protein aggregates by molecular chaperones. Journal of Structural Biology 135, 84-93.

Bennett, E. J., Bence, N. F., Jayakumar, R. \& Kopito, R. R. (2005). Global impairment of the ubiquitinproteasome system by nuclear or cytoplasmic protein aggregates precedes inclusion body formation. Molecular Cell 17, 351-365.

Berke, S. J. \& Paulson, H. L. (2003). Protein aggregation and the ubiquitin proteasome pathway: gaining the upper hand on neurodegeneration. Current Opinion in Genetics \& Development 13, 253-261.

Bhatia, R., Lin, H. \& Lal, R. (2000). Fresh and globular amyloid beta protein (1-42) induces rapid cellular degeneration: evidence for AbetaP channel-mediated cellular toxicity. FASEB Journal 14, 1233-1243.
Brown JR., R. H. (1997). Amyotrophic lateral sclerosis. Insights from genetics. Archives of Neurology 54, 12461250.

Brujn, L. I., Houseweart, M. K., Kato, S., Anderson, K. L., Anderson, S. D., Ohama, E., Reaume, A. G., Scott, R. W. \& Cleveland, D. W. (1998). Aggregation and motor neuron toxicity of an ALS-linked SOD1 mutant independent from wild-type SOD1. Science 281, 1851-1854.

Bucciantini, M., Giannoni, E., Chiti, F., Baroni, F., Formigl, L., Zurdo, J., Taddei, N., Ramponi, G., Dobson, C. M. \& Stefani, M. (2002). Inherent toxicity of aggregates implies a common mechanism for protein misfolding diseases. Nature 416, 507-511.

Butler, A. E., Janson, J., Soeller, W. C. \& Butler, P. C. (2003). Increased beta-cell apoptosis prevents adaptive increase in beta-cell mass in mouse model of type 2 diabetes: evidence for role of islet amyloid formation rather than direct action of amyloid. Diabetes 52, 2304-2314.

Cabiaux, V., Wolff, C. \& Ruysschaert, J. M. (1997). Interaction with a lipid membrane: a key step in bacterial toxins virulence. International Journal of Biological Macromolecules 21, 285-298.

Cappai, R., Leck, S. L., Tew, D. J., Williamson, N. A., Smith, D. P., Galatis, D., Sharples, R. A., Curtain, C. C., Ali, F. E., Cherny, R. A., Culvenor, J. G., Bottomley, S. P., Masters, C. L., Barnham, K. J. \& Hill, A. F. (2005). Dopamine promotes alphasynuclein aggregation into SDS-resistant soluble oligomers via a distinct folding pathway. FASEB Journal 19, 1377-1379.

Cardoso, I., Goldsbury, C. S., Muller, S. A., Olivieri, V., Wirtz, S., Damas, A. M., Aebi, U. \& Saraiva, M. J. (2002a). Transthyretin fibrillogenesis entails the assembly of monomers: a molecular model for in vitro assembled transthyretin amyloid-like fibrils. Journal of Molecular Biology 317, 683-695.

Cardoso, R. M., Thayer, M. M., Didonato, M., Lo, T. P., Bruns, C. K., Getzoff, E. D. \& TAiner, J. A. (2002b). Insights into Lou Gehrig's disease from the structure and instability of the $\mathrm{A} 4 \mathrm{~V}$ mutant of human $\mathrm{Cu}, \mathrm{Zn}$ superoxide dismutase. Journal of Molecular Biology 324, 247-256.

Caughey, B. \& Lansbury, P. T. (2003). Protofibrils, pores, fibrils, and neurodegeneration: separating the responsible protein aggregates from the innocent bystanders. Annual Review of Neuroscience 26, 267-298.

Chen, L. \& Feany, M. B. (2005). Alpha-synuclein phosphorylation controls neurotoxicity and inclusion formation in a Drosophila model of Parkinson disease. Nature Neuroscience 8, 657-663.

Chiesa, R. \& Harris, D. A. (2001). Prion diseases: what is the neurotoxic molecule? Neurobiology of Disease Journal 8, 743-763. 
Chiesa, R., Piccardo, P., Quaglio, E., Drisaldi, B., SiHoe, S. L., Takao, M., Ghetti, B. \& Harris, D. A. (2003). Molecular distinction between pathogenic and infectious properties of the prion protein. Journal of Virology 77, 7611-7622.

Chromy, B. A., Nowak, R. J., Lambert, M. P., Viola, K. L., Chang, L., Velasco, P. T., Jones, B. W., Fernandez, S. J., Lacor, P. N., Horowitz, P., Finch, C. E., Krafft, G. A. \& Klein, W. L. (2003). Selfassembly of Abeta (1-42) into globular neurotoxins. Biochemistry 42, 12749-12760.

Chui, D. H., Tanahashi, H., Ozawa, K., Ikeda, S., Checler, F., Ueda, O., Suzuki, H., Araki, W., Inoue, H., Shirotani, K., Takahashi, K., Gallyas, F. \& TABIRA, T. (1999). Transgenic mice with Alzheimer presenilin 1 mutations show accelerated neurodegeneration without amyloid plaque formation. Nature Medicine 5, 560-564.

Chung, J., Yang, H., De Beus, M. D., Ryu, C. Y., Cho, K, Colon, W. (2003). Cu/Zn superoxide dismutase can form pore-like structures. Biochemical and Biophysical Research Communications 312, 873-876.

Cleary, J. P., Walsh, D. M., Hofmeister, J. J., Shankar, G. M., Kuskowski, M. A., Selkoe, D. J. \& Ashe, K. H. (2005). Natural oligomers of the amyloid-beta protein specifically disrupt cognitive function. Nature Neuroscience 8 , 79-84.

Cohen, F. E. \& Prusiner, S. B. (1998). Pathologic conformations of prion proteins. Annual Review of Biochemistry 67, 793-819.

Conway, K. A., Harper, J. D. \& Lansbury, P. T. (1998). Accelerated in vitro fibril formation by a mutant alphasynuclein linked to early-onset Parkinson disease. Nature Medicine 4, 1318-1320.

Conway, K. A., Lee, S. J., Rochet, J. C., Ding, T. T., Williamson, R. E. \& Lansbury Jr., P. T. (2000). Acceleration of oligomerization, not fibrillization, is a shared property of both alpha-synuclein mutations linked to early-onset Parkinson's disease: implications for pathogenesis and therapy. Proceedings of the National Academy of Sciences USA 97, 571-576.

Conway, K. A., Rochet, J. C., Bieganski, R. M. \& Lansbury JR., P. T. (2001). Kinetic stabilization of the alpha-synuclein protofibril by a dopamine-alphasynuclein adduct. Science 294, 1346-1349.

Cookson, M. R. (2005). The biochemistry of Parkinson's disease. Annual Review of Biochemistry 74, 29-52.

Crystal, A. S., Giasson, B. I., Crowe, A., Kung, M. P., Zhuang, Z. P., Trojanowski, J. Q. \& Lee, V. M. (2003). A comparison of amyloid fibrillogenesis using the novel fluorescent compound K114. Journal of Neurochemistry 86, 1359-1368.

Curtain, C. C., Ali, F. E., Smith, D. G., Bush, A. I., Masters, C. L. \& Barnham, K. J. (2003). Metal ions, pH, and cholesterol regulate the interactions of Alzheimer's disease amyloid-beta peptide with membrane lipid. Journal of Biological Chemistry 278, 2977-2982.

Dahlgren, K. N., Manelli, A. M., Stine Jr., W. B., Baker, L. K., Krafft, G. A. \& Ladu, M. J. (2002). Oligomeric and fibrillar species of amyloid-beta peptides differentially affect neuronal viability. Journal of Biological Chemistry 277, 32046-32053.

Dauer, W. \& Przedborski, S. (2003). Parkinson's disease: mechanisms and models. Neuron 39, 889-909.

De Koning, E. J., Hoppener, J. W., Verbeek, J. S., Oosterwijk, C., Van Hulst, K. L., Baker, C. A., Lips, C. J., Morris, J. F. \& Clark, A. (1994). Human islet amyloid polypeptide accumulates at similar sites in islets of transgenic mice and humans. Diabetes 43, 640-644.

Demuro, A., Mina, E., Kayed, R., Milton, S. C., Parker, I. \& Glabe, C. G. (2005). Calcium dysregulation and membrane disruption as a ubiquitous neurotoxic mechanism of soluble amyloid oligomers. Journal of Biological Chemistry 280, 17294-17300.

Ding, T. T., Lee, S. J., Rochet, J. C. \& Lansbury Jr., P. T. (2002). Annular alpha-synuclein protofibrils are produced when spherical protofibrils are incubated in solution or bound to brain-derived membranes. Biochemistry 41, 10209-10217.

Dobson, C. M. (2001). The structural basis of protein folding and its links with human disease. Philosophical Transactions of the Royal Society B: Biological Sciences 356, 133-145.

Dzwolak, W., Grudzielanek, S., Smirnovas, V., Ravindra, R., Nicolini, C., Jansen, R., Loksztejn, A., Porowski, S. \& Winter, R. (2005). Ethanol-perturbed amyloidogenic self-assembly of insulin: looking for origins of amyloid strains. Biochemistry 44, 8948-8958.

Eckert, G. P., Kirsch, C., Leutz, S., Wood, W. G. \& Muller, W. E. (2003). Cholesterol modulates amyloid beta-peptide's membrane interactions. Pharmacopsychiatry 36 (Suppl. 2), S136-S143.

El-Agnaf, O. M., Jakes, R., Curran, M. D. \& Wallace, A. (1998). Effects of the mutations Ala30 to Pro and Ala53 to Thr on the physical and morphological properties of alpha-synuclein protein implicated in Parkinson's disease. FEBS Letters 440, 67-70.

El-Agnaf, O. M., Mahil, D. S., Patel, B. P. \& Austen, B. M. (2000). Oligomerization and toxicity of betaamyloid-42 implicated in Alzheimer's disease. Biochemical and Biophysical Research Communications 273, 1003-1007.

El-Agnaf, O. M., Nagala, S., Patel, B. P. \& Austen, B. M. (2001a). Non-fibrillar oligomeric species of the amyloid ABri peptide, implicated in familial British dementia, are more potent at inducing apoptotic cell death than protofibrils or mature fibrils. Journal of Molecular Biology 310, 157-168.

El-Agnaf, O. M., Salem, S. A., Paleologou, K. E., Curran, M. D., Gibson, M. J., Court, J. A., Schlossmacher, M. G. \& Allsop, D. (2006). Detection 
of oligomeric forms of alpha-synuclein protein in human plasma as a potential biomarker for Parkinson's disease. FASEB Journal 20, 419-425.

El-Agnaf, O. M., Sheridan, J. M., Sidera, C., Siligardi, G., Hussain, R., Haris, P. I. \& Austen, B. M. (2001b). Effect of the disulfide bridge and the C-terminal extension on the oligomerization of the amyloid peptide ABri implicated in familial British dementia. Biochemistry 40, 3449-3457.

Elam, J. S., Taylor, A. B., Strange, R., Antonyuk, S., Doucette, P. A., Rodriguez, J. A., Hasnain, S. S., Hayward, L. J., Valentine, J.S., Yeates, T. O. \& Hart, P. J. (2003). Amyloid-like filaments and waterfilled nanotubes formed by SOD1 mutant proteins linked to familial ALS. Nature Structural Biology 10, 461-467.

Falsey, A. R., Walsh, E. E., Francis, C. W., Looney, R. J., Kolassa, J. E., Hall, W. J. \& Abraham, G. N. (2001). Response of C-reactive protein and serum amyloid A to influenza A infection in older adults. Journal of Infectious Diseases 183, 995-999.

Feany, M. B. \& Bender, W. W. (2000). A Drosophila model of Parkinson's disease. Nature 404, 394-398.

Ferrington, D. A., Husom, A. D. \& Thompson, L. V. (2005). Altered proteasome structure, function, and oxidation in aged muscle. FASEB Journal 19, 644-646.

Flynn, B. L. \& Theesen, K. A. (1999). Pharmacologic management of Alzheimer disease part III: nonsteroidal antiinflammatory drugs - emerging protective evidence? Annals of Pharmacotherapy 33, 840-849.

Fujiwara, H., Hasegawa, M., Dohmae, N., Kawashima, A., Masliah, E., Goldberg, M. S., Shen, J., Takio, K. \& Iwatsubo, T. (2002). alpha-Synuclein is phosphorylated in synucleinopathy lesions. Nature Cell Biology 4, 160-164.

Funato, H., Enya, M., Yoshimura, M., MorishimaKawashima, M. \& Ihara, Y. (1999). Presence of sodium dodecyl sulfate-stable amyloid beta-protein dimers in the hippocampus CA1 not exhibiting neurofibrillary tangle formation. American Journal of Pathology 155, 23-28.

Fussle, R., Bhakdi, S., Sziegoleit, A., Tranum-Jensen, J., Kranz, T. \& Wellensiek, H. J. (1981). On the mechanism of membrane damage by Staphylococcus aureus alpha-toxin. Journal of Cell Biology 91, 83-94.

Gaczynska, M., Osmulski, P. A. \& Ward, W. F. (2001). Caretaker or undertaker? The role of the proteasome in aging. Mechanisms of Ageing and Development 122, 235-254.

Gambetti, P., Parchi, P., Petersen, R. B., Chen, S. G. \& LugAresi, E. (1995). Fatal familial insomnia and familial Creutzfeldt-Jakob disease: clinical, pathological and molecular features. Brain Pathology 5, 43-51.

Ghiso, J., Vidal, R., Rostagno, A., Miravalle, L., Holton, J. L., Mead, S., Revesz, T., Plant, G. \& Frangione, B. (2000). Amyloidogenesis in familial British dementia is associated with a genetic defect on chromosome 13. Annals of the New York Academy of Sciences 920, 84-92.

Giasson, B. I. \& LeE, V. M. (2003). Are ubiquitination pathways central to Parkinson's disease? Cell 114, 1-8.

Glenner, G. G. \& Wong, C. W. (1984). Alzheimer's disease: initial report of the purification and characterization of a novel cerebrovascular amyloid protein. Biochemical and Biophysical Research Communications 120, 885-890.

Goldberg, M. S. \& Lansbury Jr., P. T. (2000). Is there a cause-and-effect relationship between alpha-synuclein fibrillization and Parkinson's disease? Nature Cell Biology 2, E115-E119.

Goldsbury, C., Frey, P., Olivieri, V., Aebi, U. \& Muller, S. A. (2005). Multiple assembly pathways underlie amyloid-beta fibril polymorphisms. Journal of Molecular Biology 352, 282-298.

Gong, Y., Chang, L., Viola, K. L., Lacor, P. N., Lambert, M. P., Finch, C. E., Krafft, G. A. \& Klein, W. L. (2003). Alzheimer's disease-affected brain: presence of oligomeric A beta\} ligands (ADDLs) suggests a molecular basis for reversible memory loss. Proceedings of the National Academy of Sciences USA 100, 10417-10422.

Gosavi, N., Lee, H. J., Lee, J. S., Patel, S. \& Lee, S. J. (2002). Golgi fragmentation occurs in the cells with prefibrillar alpha-synuclein aggregates and precedes the formation of fibrillar inclusion. Journal of Biological Chemistry 277, 48984-48992.

Green, J., Goldsbury, C., Mini, T., Sunderji, S., Frey, P., Kistler, J., Cooper, G. \& Aebi, U. (2003). Full-length rat amylin forms fibrils following substitution of single residues from human amylin. Journal of Molecular Biology 326, 1147-1156.

Green, J. D., Goldsbury, C., Kistler, J., Cooper, G. S. \& Aebi, U. (2004). Human amylin oligomer growth and fibril elongation define two distinct phases in amyloid formation. Journal of Biological Chemistry 279, $12206-$ 12212.

Hafner, J. H., Cheung, C. L., Woolley, A. T. \& Lieber, C. M. (2001). Structural and functional imaging with carbon nanotube AFM probes. Progress in Biophysics \& Molecular Biology 77, 73-110.

Hardy, J. \& Selkoe, D. J. (2002). The amyloid hypothesis of Alzheimer's disease: progress and problems on the road to therapeutics. Science 297, 353-356.

Hardy, J. A. \& Higgins, G. A. (1992). Alzheimer's disease: the amyloid cascade hypothesis. Science 256, 184-185.

Harper, J. D., Lieber, C. M. \& Lansbury Jr., P. T. (1997a). Atomic force microscopic imaging of seeded fibril formation and fibril branching by the Alzheimer's disease amyloid-beta protein. Chemistry \& Biology 4, 951-959.

Harper, J. D., Wong, S. S., Lieber, C. M. \& Lansbury, P. T. (1997b). Observation of metastable Abeta 
amyloid protofibrils by atomic force microscopy. Chemistry \& Biology 4, 119-125.

Harper, J. D., Wong, S. S., Lieber, C. M. \& Lansbury Jr., P. T. (1999). Assembly of A beta amyloid protofibrils: an in vitro model for a possible early event in Alzheimer's disease. Biochemistry 38, 8972-8980.

Harris, D. A., Chiesa, R., Drisaldi, B., Quaglio, E., Migheli, A., Piccardo, P. \& Ghetti, B. (2003). A murine model of a familial prion disease. Clinical Laboratory Medicine 23, 175-186.

Harroun, T. A., Bradshaw, J. P. \& Ashley, R. H. (2001). Inhibitors can arrest the membrane activity of human islet amyloid polypeptide independently of amyloid formation. FEBS Letters 507, 200-204.

Hartley, D. M., Walsh, D. M., Ye, C. P., Diehl, T., Vasquez, S., Vassilev, P. M., Teplow, D. B. \& Selkoe, D. J. (1999). Protofibrillar intermediates of amyloid beta-protein induce acute electrophysiological changes and progressive neurotoxicity in cortical neurons. Journal of Neuroscience 19, 8876-8884.

Hashimoto, M., Rockenstein, E., Mante, M., Mallory, M. \& Masliah, E. (2001). beta-Synuclein inhibits alpha-synuclein aggregation: a possible role as an antiparkinsonian factor. Neuron 32, 213-223.

Hayward, L. J., Rodriguez, J. A., Kim, J. W., Tiwari, A., Goto, J. J., Cabelli, D. E., Valentine, J. S. \& Brown JR., R. H. (2002). Decreased metallation and activity in subsets of mutant superoxide dismutases associated with familial amyotrophic lateral sclerosis. Journal of Biological Chemistry 277, 15923-15931.

Hegde, R. S., Tremblay, P., Groth, D., Dearmond, S. J., Prusiner, S. B. \& Lingappa, V. R. (1999). Transmissible and genetic prion diseases share a common pathway of neurodegeneration. Nature 402, 822-826.

Helms, L. R. \& WeTzel, R. (1996). Specificity of abnormal assembly in immunoglobulin light chain deposition disease and amyloidosis. Journal of Molecular Biology 257, $77-86$.

Heuck, A. P., Tweten, R. K. \& Johnson, A. E. (2001). Beta-barrel pore-forming toxins: intriguing dimorphic proteins. Biochemistry 40, 9065-9073.

Heuck, A. P., Tweten, R. K. \& Johnson, A. E. (2003). Assembly and topography of the prepore complex in cholesterol-dependent cytolysins. Journal of Biological Chemistry 278, 31218-31225.

Heydari, A. R., Conrad, C. C. \& Richardson, A. (1995). Expression of heat shock genes in hepatocytes is affected by age and food restriction in rats. Journal of Nutrition 125, 410-418.

Hirakura, Y., Azimov, R., Azimova, R. \& Kagan, B. L. (2000a). Polyglutamine-induced ion channels: a possible mechanism for the neurotoxicity of Huntington and other CAG repeat diseases. Journal of Neuroscience Research 60, 490-494.

Hirakura, Y., Carreras, I., Sipe, J. D. \& Kagan, B. L. (2002). Channel formation by serum amyloid A: a potential mechanism for amyloid pathogenesis and host defense. Amyloid 9, 13-23.

Hirakura, Y. \& Kagan, B. L. (2001). Pore formation by beta-2-microglobulin: a mechanism for the pathogenesis of dialysis associated amyloidosis. Amyloid $\mathbf{8}$, 94-100.

Hirakura, Y., Lin, M. C. \& Kagan, B. L. (1999). Alzheimer amyloid abeta 1-42 channels: effects of solvent, $\mathrm{pH}$, and Congo Red. Journal of Neuroscience Research 57, 458-466.

Hirakura, Y., Yiu, W. W., Yamamoto, A. \& Kagan, B. L. (2000b). Amyloid peptide channels: blockade by zinc and inhibition by Congo red (amyloid channel block). Amyloid 7, 194-199.

Hirsch, E. C., Faucheux, B., Damier, P., MouattPrigent, A. \& Agid, Y. (1997). Neuronal vulnerability in Parkinson's disease. Journal of Neural Transmission $\mathbf{5 0}$ (Suppl.), 79-88.

Holton, J. L., Ghiso, J., Lashley, T., Rostagno, A., Guerin, C. J., Gibb, G., Houlden, H., Ayling, H., Martinian, L., Anderton, B. H., Wood, N. W., Vidal, R., Plant, G., Frangione, B. \& Revesz, T. (2001). Regional distribution of amyloid-Bri deposition and its association with neurofibrillary degeneration in familial British dementia. American Journal of Pathology 158, 515-526.

Hoshi, M., Sato, M., Matsumoto, S., Noguchi, A., Yasutake, K., Yoshida, N. \& Sato, K. (2003). Spherical aggregates of beta-amyloid (amylospheroid) show high neurotoxicity and activate tau protein kinase I/glycogen synthase kinase-3beta. Proceedings of the National Academy of Sciences USA 100, 63706375.

Hotze, E. M., Wilson-Kubalek, E. M., Rossjohn, J., Parker, M. W., Johnson, A. E. \& Tweten, R. K. (2001). Arresting pore formation of a cholesteroldependent cytolysin by disulfide trapping synchronizes the insertion of the transmembrane beta-sheet from a prepore intermediate. Journal of Biological Chemistry 276, 8261-8268.

Hsia, A. Y., Masliah, E., Mcconlogue, L., Yu, G. Q., Tatsuno, G., Hu, K., Kholodenko, D., Malenka, R. C., Nicoll, R. A. \& Mucke, L. (1999). Plaqueindependent disruption of neural circuits in Alzheimer's disease mouse models. Proceedings of the National Academ of Sciences USA 96, 3228-3233.

Huang, T. H., Yang, D. S., Plaskos, N. P., Go, S., Yip, C. M., Fraser, P. E. \& Chakrabartty, A. (2000). Structural studies of soluble oligomers of the Alzheimer beta-amyloid peptide. Journal of Molecular Biology 297, 73-87.

Ishimaru, D., Andrade, L. R., Teixeira, L. S., Quesado, P. A., Maiolino, L. M., Lopez, P. M., Cordeiro, Y., Costa, L. T., Heckl, W. M., Weissmuller, G., Foguel, D. \& SiLVA, J. L. (2003). Fibrillar aggregates of the 
tumor suppressor p53 core domain. Biochemistry 42, 9022-9027.

Janson, J., Ashley, R. H., Harrison, D., Mcintyre, S. \& Butler, P. C. (1999). The mechanism of islet amyloid polypeptide toxicity is membrane disruption by intermediate-sized toxic amyloid particles. Diabetes 48, 491-498.

Janson, J., Soeller, W. C., Roche, P. C., Nelson, R. T., Torchia, A. J., Kreutter, D. K. \& Butler, P. C. (1996). Spontaneous diabetes mellitus in transgenic mice expressing human islet amyloid polypeptide. Proceedings of the National Academy of Sciences USA 93, 7283-7288.

Janus, C., Pearson, J., Mclaurin, J., Mathews, P. M., Jiang, Y., Schmidt, S. D., Chishti, M. A., Horne, P., Heslin, D., French, J., Mount, H. T., Nixon, R. A., Mercken, M., Bergeron, C., Fraser, P. E., St George-Hyslop, P. \& Westaway, D. (2000). A beta peptide immunization reduces behavioural impairment and plaques in a model of Alzheimer's disease. Nature 408, 979-982.

Jarrett, J. T., Berger, E. P. \& Lansbury Jr., P. T. (1993). The carboxy terminus of the beta amyloid protein is critical for the seeding of amyloid formation: implications for the pathogenesis of Alzheimer's disease. Biochemistry 32, 4693-4697.

Jarrett, J. T. \& Lansbury JR., P. T. (1993). Seeding 'onedimensional crystallization' of amyloid: a pathogenic mechanism in Alzheimer's disease and scrapie? Cell 73, 1055-1058.

Johnston, J. A., Dalton, M. J., Gurney, M. E. \& Kopito, R. R. (2000). Formation of high molecular weight complexes of mutant $\mathrm{Cu}, \mathrm{Zn}$-superoxide dismutase in a mouse model for familial amyotrophic lateral sclerosis. Proceedings of the National Academy of Sciences USA 97, 12571-12576.

Johnston, J. A., Ward, C. L. \& Kopito, R. R. (1998). Aggresomes: a cellular response to misfolded proteins. Journal of Cell Biology 143, 1883-1898.

Julien, J. P. (2001). Amyotrophic lateral sclerosis. unfolding the toxicity of the misfolded. Cell 104, 581-591.

Junn, E., Lee, S. S., Suhr, U. T. \& Mouradian, M. M. (2002). Parkin accumulation in aggresomes due to proteasome impairment. Journal of Biological Chemistry 277, 47870-47877.

Kad, N. M., Myers, S. L., Smith, D. P., Smith, D. A., RAdford, S. E. \& Thomson, N. H. (2003). Hierarchical assembly of beta2-microglobulin amyloid in vitro revealed by atomic force microscopy. Journal of Molecular Biology 330, 785-797.

Kagan, B. L., Hirakura, Y., Azimov, R. \& Azimova, R. (2001). The channel hypothesis of Huntington's disease. Brain Research Bulletin 56, 281-284.

Kagan, B. L., Hirakura, Y., Azimov, R., Azimova, R. \& Lin, M. C. (2002). The channel hypothesis of Alzheimer's disease: current status. Peptides 23, 1311-1315.
Kawahara, M., Arispe, N., Kuroda, Y. \& Rojas, E. (1997). Alzheimer's disease amyloid beta-protein forms Zn (2+)-sensitive, cation-selective channels across excised membrane patches from hypothalamic neurons. Biophysical Journal 73, 67-75.

Kawahara, M. \& Kuroda, Y. (2000). Molecular mechanism of neurodegeneration induced by Alzheimer's betaamyloid protein: channel formation and disruption of calcium homeostasis. Brain Research Bulletin 53, 389-397.

KAWAHARA, M. \& KURODA, Y. (2001). Intracellular calcium changes in neuronal cells induced by Alzheimer's betaamyloid protein are blocked by estradiol and cholesterol. Cellular and Molecular Neurobiology 21, 1-13.

Kawahara, M., Kuroda, Y., Arispe, N. \& Rojas, E. (2000). Alzheimer's beta-amyloid, human islet amylin, and prion protein fragment evoke intracellular free calcium elevations by a common mechanism in a hypothalamic GnRH neuronal cell line. Journal of Biological Chemistry 275, 14077-14083.

KAyed, R. \& Glabe, C. G. (2004). Formation, stability and toxicity of annular protofibrils from different amyloid forming proteins. Neurobiology of Aging 25 (Suppl. 2), S144.

Kayed, R., Head, E., Thompson, J. L., Mcintire, T. M., Milton, S. C., Cotman, C. W. \& Glabe, C. G. (2003). Common structure of soluble amyloid oligomers implies common mechanism of pathogenesis. Science 300, 486-489.

Kayed, R., Sokolov, Y., Edmonds, B., Mcintire, T. M., Milton, S. C., Hall, J. E. \& Glabe, C. G. (2004). Permeabilization of lipid bilayers is a common conformation-dependent activity of soluble amyloid oligomers in protein misfolding diseases. Journal of Biological Chemistry 279, 46363-46366.

Kaylor, J., Bodner, N., Edridge, S., Yamin, G., Hong, D. P. \& FINK, A. L. (2005). Characterization of oligomeric intermediates in alpha-synuclein fibrillation: FRET studies of Y125W/Y133F/Y136F alpha-synuclein. Journal of Molecular Biology 353, 357-372.

KeLLY, J. W. (1998). The alternative conformations of amyloidogenic proteins and their multi-step assembly pathways. Current Opinion in Structural Biology 8, 101-106.

Kheterpal, I., Lashuel, H., Hartley, D., Walz, T., Lansbury Jr., P. \& Wetzel, R. (2003). Aß protofibrils possess a stable core structure resistant to hydrogen exchange. Biochemistry 42, 14092-14098.

Kim, H. J., Chae, S. C., Lee, D. K., Chromy, B., Lee, S. C., Park, Y. C., Klein, W. L., Krafft, G. A. \& Hong, S. T. (2003). Selective neuronal degeneration induced by soluble oligomeric amyloid beta protein. FASEB Journal 17, 118-120.

Kirik, D., Annett, L. E., Burger, C., Muzyczka, N., Mandel, R. J. \& Bjorklund, A. (2003). Nigrostriatal alpha-synucleinopathy induced by viral vector-mediated overexpression of human alpha-synuclein: a new 
primate model of Parkinson's disease. Proceedings of the National Academy of Sciences USA 100, 2884-2889.

Kirik, D., Rosenblad, C., Burger, C., Lundberg, C., Johansen, T. E., Muzyczka, N., Mandel, R. J. \& Bjorklund, A. (2002). Parkinson-like neurodegeneration induced by targeted overexpression of alpha-synuclein in the nigrostriatal system. Journal of Neuroscience 22, 2780-2791.

Kitada, T., Asakawa, S., Hattori, N., Matsumine, H., Yamamura, Y., Minoshima, S., Yokochi, M., Mizuno, Y. \& SHImizu, N. (1998). Mutations in the parkin gene cause autosomal recessive juvenile parkinsonism. Nature 392, 605-608.

Klug, G. M., Losic, D., Subasinghe, S. S., Aguilar, M. I., Martin, L. L. \& Small, D. H. (2003). Beta-amyloid protein oligomers induced by metal ions and acid $\mathrm{pH}$ are distinct from those generated by slow spontaneous ageing at neutral $\mathrm{pH}$. European Journal of Biochemistry 270, 4282-4293.

Kopito, R. R. (2000). Aggresomes, inclusion bodies and protein aggregation. Trends in Cell Biology 10, 524-530.

Kourie, J. I. (2002). Prion channel proteins and their role in vacuolation and neurodegenerative diseases. European Biophysics Journal 31, 409-416.

Kourie, J. I. \& Culverson, A. (2000). Prion peptide fragment $\operatorname{Pr} \mathrm{P}[106-126]$ forms distinct cation channel types. Journal of Neuroscience Research 62, 120-133.

Kourie, J. I., Farrelly, P. V. \& Henry, C. L. (2001a). Channel activity of deamidated isoforms of prion protein fragment 106-126 in planar lipid bilayers. Journal of Neuroscience Research 66, 214-220.

Kourie, J. I., Henry, C. L. \& Farrelly, P. (2001b). Diversity of amyloid beta protein fragment [1-40]formed channels. Cellular and Molecular Neurobiology 21, 255-284.

Kourie, J. I., Kenna, B. L., Tew, D., Jobling, M. F., Curtain, C. C., Masters, C. L., Barnham, K. J. \& Cappai, R. (2003). Copper modulation of ion channels of $\operatorname{Pr}$ [106-126] mutant prion peptide fragments. Journal of Membrane Biology 193, 35-45.

Kruger, R., Kuhn, W., Muller, T., Woitalla, D., Graeber, M., Kosel, S., Przuntek, H., Epplen, J. T., Schols, L. \& Riess, O. (1998). Ala30Pro mutation in the gene encoding alpha-synuclein in Parkinson's disease. Nature Genetics 18, 106-108.

Kuemmerle, S., Gutekunst, C. A., Klein, A. M., Li, X. J., Li, S. H., Beal, M. F., Hersch, S. M. \& Ferrante, R. J. (1999). Huntington aggregates may not predict neuronal death in Huntington's disease. Annals of Neurology 46, 842-849.

Kuo, Y. M., Emmerling, M. R., Vigo-Pelfrey, C., Kasunic, T. C., Kirkpatrick, J. B., Murdoch, G. H., Ball, M. J. \& Roher, A. E. (1996). Water-soluble Abeta (N-40, N-42) oligomers in normal and Alzheimer disease brains. Journal of Biological Chemistry 271, 4077-4081.
Lambert, M. P., Barlow, A. K., Chromy, B. A., Edwards, C., Freed, R., Liosatos, M., Morgan, T. E., Rozoviky, I., Trommer, B., Viola, K. L., Wals, P., Zhang, C., Finch, C. E., Krafft, G. A. \& Klein, W. L. (1998). Diffusible, nonfibrillar ligands derived from Abeta1-42 are potent central nervous system neurotoxins. Proceedings of the National Academy of Sciences USA 95, 6448-6453.

Lambert, M. P., Viola, K. L., Chromy, B. A., Chang, L., Morgan, T. E., Yu, J., Venton, D. L., Krafft, G. A., FINCH, C. E. \& KLeIN, W. L. (2001). Vaccination with soluble Abeta oligomers generates toxicity-neutralizing antibodies. Journal of Neurochemistry 79, 595-605.

Lansbury Jr., P. T. \& Brice, A. (2002). Genetics of Parkinson's disease and biochemical studies of implicated gene products. Current Opinion in Genetics \& Development 12, 299-306.

Lashuel, H., Hartley, D., Petre, B., Wall, J., Simon, M., Walz, T. \& Lansbury, P. (2003). Mixtures of wild-type and 'Arctic' Abeta40 in vitro accumulate protofibrils, including amyloid pores. Journal of Molecular Biology 332, 795-808.

Lashuel, H., Petre, B., Wall, J., Simon, M., Nowak, R., Walz, T. \& Lansbury, P. (2002a). alpha-Synuclein, Especially the Parkinson's Disease-associated Mutants, Forms Pore-like Annular and Tubular Protofibrils. Journal of Molecular Biology 322, 1089.

Lashuel, H. A., Hartley, D., Petre, B. M., Walz, T. \& Lansbury JR., P. T. (2002b). Neurodegenerative disease: amyloid pores from pathogenic mutations. Nature 418, 291 .

Lashuel, H. A., Lai, Z. \& Kelly, J. W. (1998). Characterization of the transthyretin acid denaturation pathways by analytical ultracentrifugation: implications for wild-type, V30M, and L55P amyloid fibril formation. Biochemistry 37, 17851-17864.

Lashuel, H. A., Wurth, C., Woo, L. \& Kelly, J. W. (1999). The most pathogenic transthyretin variant, L55P, forms amyloid fibrils under acidic conditions and protofilaments under physiological conditions. Biochemistry 38, 13560-13573.

Lee, H. J., Khoshaghideh, F., Patel, S. \& Lee, S. J. (2004). Clearance of alpha-synuclein oligomeric intermediates via the lysosomal degradation pathway. Journal of Neuroscience 24, 1888-1896.

LeE, H. J. \& LeE, S. J. (2002). Characterization of cytoplasmic alpha-synuclein aggregates: Fibril formation is tightly linked to the inclusion forming process in cells. Journal of Biological Chemistry 277, 48976-48983.

Lee, H. J., Shin, S. Y., Choi, C., Lee, Y. H. \& Lee, S. J. (2002). Formation and removal of alpha-synuclein aggregates in cells exposed to mitochondrial inhibitors. Journal of Biological Chemistry 277, 5411-5417.

Lee, S. \& Eisenberg, D. (2003). Seeded conversion of recombinant prion protein to a disulfide-bonded 
oligomer by a reduction-oxidation process. Nature Structural Biology 10, 725-730.

Lehmann, S. \& Harris, D. A. (1996). Mutant and infectious prion proteins display common biochemical properties in cultured cells. Journal of Biological Chemistry 271, 1633-1637.

Lemere, C. A., Blusztajn, J. K., Yamaguchi, H., Wisniewski, T., Saido, T. C. \& Selkoe, D. J. (1996). Sequence of deposition of heterogeneous amyloid betapeptides and APO E in Down syndrome: implications for initial events in amyloid plaque formation. Neurobiology of Disease Journal 3, 16-32.

Leroy, E., Boyer, R., Auburger, G., Leube, B., Ulm, G., Mezey, E., Harta, G., Brownstein, M. J., Jonnalagada, S., Chernova, T., Dehejia, A., Lavedan, C., Gasser, T., Steinbach, P. J., Wilkinson, K. D. \& Polymeropoulos, M. H. (1998). The ubiquitin pathway in Parkinson's disease. Nature 395, 451-452.

Li, J., Uversky, V. N. \& Fink, A. L. (2001). Effect of familial Parkinson's disease point mutations A30P and A53T on the structural properties, aggregation, and fibrillation of human alpha-synuclein. Biochemistry 40, 11604-11613.

Li, J., Zhu, M., Manning-Bog, A. B., Di Monte, D. A. \& FINK, A. L. (2004). Dopamine and L-dopa disaggregate amyloid fibrils: implications for Parkinson's and Alzheimer's disease. FASEB Journal 18, 962-964.

Lin, H., Bhatia, R. \& Lal, R. (2001). Amyloid beta protein forms ion channels: implications for Alzheimer's disease pathophysiology. FASEB Journal 15, 2433-2444.

Lin, H., ZHU, Y. J. \& LAL, R. (1999). Amyloid beta protein (1-40) forms calcium-permeable, $\mathrm{Zn}^{2+}$-sensitive channel in reconstituted lipid vesicles. Biochemistry 38, 11189-11196.

Lin, M. C. \& KaGAN, B. L. (2002). Electrophysiologic properties of channels induced by Abeta25-35 in planar lipid bilayers. Peptides 23, 1215-1228.

Lin, M. C., Mirzabekov, T. \& Kagan, B. L. (1997). Channel formation by a neurotoxic prion protein fragment. Journal of Biological Chemistry 272, 44-47.

Lindberg, M. J., Tibell, L. \& Oliveberg, M. (2002). Common denominator of $\mathrm{Cu} / \mathrm{Zn}$ superoxide dismutase mutants associated with amyotrophic lateral sclerosis: decreased stability of the apo state. Proceedings of the National Academy of Sciences USA 99, 16607-16612.

Lindersson, E., Beedholm, R., Hojrup, P., Moos, T., Gai, W., Hendil, K. B. \& Jensen, P. H. (2004). Proteasomal inhibition by $\alpha$-synuclein filaments and oligomers. Journal of Biological Chemistry 279, 12924-12934.

Lo Bianco, C., Ridet, J. L., Schneider, B. L., Deglon, N. \& Aebischer, P. (2002). alpha-Synucleinopathy and selective dopaminergic neuron loss in a rat lentiviralbased model of Parkinson's disease. Proceedings of the National Academy of Sciences USA 99, 10813-10818.
Lotharius, J. \& Brundin, P. (2002). Pathogenesis of Parkinson's disease: dopamine, vesicles and alphasynuclein. Nature Reviews Neuroscience 3, 932-942.

Lowe, R., Pountney, D. L., Jensen, P. H., Gai, W. P. \& Voelcker, N. H. (2004). Calcium(II) selectively induces alpha-synuclein annular oligomers via interaction with the C-terminal domain. Protein Science 13, 3245-3252.

Lu, B. Y. \& Chang, J. Y. (2002). Isolation and characterization of a polymerized prion protein. Biochemical Journal 364, 81-87.

Lue, L. F., Kuo, Y. M., Roher, A. E., Brachova, L., Shen, Y., Sue, L., Beach, T., Kurth, J. H., Rydel, R. E. \& Rogers, J. (1999). Soluble amyloid beta peptide concentration as a predictor of synaptic change in Alzheimer's disease. American Journal of Pathology 155, 853-862.

MA, J. \& Lindquist, S. (2002). Conversion of PrP to a selfperpetuating PrPSc-like conformation in the cytosol. Science 298, 1785-1788.

Ma, J., Wollmann, R. \& Lindquist, S. (2002). Neurotoxicity and neurodegeneration when $\operatorname{PrP}$ accumulates in the cytosol. Science 298, 1781-1785.

Maat-Schieman, M. L., Van Duinen, S. G., Haan, J. \& Roos, R. A. (1992). Morphology of cerebral plaque-like lesions in hereditary cerebral hemorrhage with amyloidosis [in Dutch]. Acta Neuropathologica (Berlin) 84, 674-679.

Malisauskas, M., Zamotin, V., Jass, J., Noppe, W., Dobson, C. M. \& Morozova-Roche, L. A. (2003). Amyloid protofilaments from the calcium-binding protein equine lysozyme: formation of ring and linear structures depends on $\mathrm{pH}$ and metal ion concentration. Journal of Molecular Biology 330, 879-890.

Masliah, E. \& Hashimoto, M. (2002). Development of new treatments for Parkinson's disease in transgenic animal models: a role for beta-synuclein. Neurotoxicology 23, 461-468.

Masliah, E., Rockenstein, E., Veinbergs, I., Mallory, M., Hashimoto, M., Takeda, A., Sagara, Y., Sisk, A. \& Mucke, L. (2000). Dopaminergic loss and inclusion body formation in alpha-synuclein mice: implications for neurodegenerative disorders. Science 287, 1265-1269.

Mcclellan, A. J., Tam, S., Kaganovich, D. \& Frydman, J. (2005). Protein quality control: chaperones culling corrupt conformations. Nature Cell Biology 7, 736-741.

Mclean, C. A., Cherny, R. A., Fraser, F. W., Fuller, S. J., Smith, M. J., Beyreuther, K., Bush, A. I. \& Masters, C. L. (1999). Soluble pool of Abeta amyloid as a determinant of severity of neurodegeneration in Alzheimer's disease. Annals of Neurology 46, 860-866.

Mcnaught, K. S., Mytilineou, C., Jnobaptiste, R., Yabut, J., Shashidharan, P., Jennert, P. \& Olanow, C. W. (2002). Impairment of the ubiquitin-proteasome system causes dopaminergic cell death and inclusion body formation in ventral mesencephalic cultures. Journal of Neurochemistry 81, 301-306. 
Menestrina, G., Serra, M. D. \& Prevost, G. (2001). Mode of action of beta-barrel pore-forming toxins of the staphylococcal alpha-hemolysin family. Toxicon 39, 1661-1672.

Menzies， F. M., Ince, P. G. \& Shaw, P. J. (2002). Mitochondrial involvement in amyotrophic lateral sclerosis. Neurochemistry International 40, 543-551.

Mirzabekov, T. A., Lin, M. C. \& Kagan, B. L. (1996). Pore formation by the cytotoxic islet amyloid peptide amylin. Journal of Biological Chemistry 271, 1988-1992.

Moechars, D., Dewachter, I., Lorent, K., Reverse, D., Baekelandt, V., Naidu, A., Tesseur, I., Spittaels, K., Haute, C. V., Checler, F., Godaux, E., Cordell, B. \& Van Leuven, F. (1999). Early phenotypic changes in transgenic mice that overexpress different mutants of amyloid precursor protein in brain. Journal of Biological Chemistry 274, 6483-6492.

Monor, H. (1995). New tubular single-stranded helix of poly-L-amino acids suggested by molecular mechanics calculations: I. Homopolypeptides in isolated environments. Biophysical Journal 69, 1130-1141.

Monoi, H., Futaki, S., Kugimiya, S., Minakata, H. \& Yoshinara, K. (2000). Poly-L-glutamine forms cation channels: relevance to the pathogenesis of the polyglutamine diseases. Biophysical Journal 78, 2892-2899.

Moore, R. C., Lee, I. Y., Silverman, G. L., Harrison, P. M., Strome, R., Heinrich, C., Karunaratne, A., Pasternak, S. H., Chishti, M. A., Liang, Y., Mastrangelo, P., Wang, K., Smit, A. F., Katamine, S., Carlson, G. A., Cohen, F. E., Prusiner, S. B., Melton, D. W., Tremblay, P., Hood, L. E. \& Westaway, D. (1999). Ataxia in prion protein $(\operatorname{PrP})$ deficient mice is associated with upregulation of the novel PrP-like protein doppel. Journal of Molecular Biology 292, 797-817.

Morgan, D., Diamond, D. M., Gottschall, P. E., Ugen, K. E., Dickey, C., Hardy, J., Duff, K., Jantzen, P., Dicarlo, G., Wilcock, D., Connor, K., Hatcher, J., Hope, C., Gordon, M. \& Arendash, G. W. (2000). A beta peptide vaccination prevents memory loss in an animal model of Alzheimer's disease. Nature 408, 982-985.

Morishima-Kawashima, M. \& Ihara, Y. (1998). The presence of amyloid beta-protein in the detergentinsoluble membrane compartment of human neuroblastoma cells. Biochemistry 37, 15247-15253.

Muchowski, P.J. (2002). Protein misfolding, amyloid formation, and neurodegeneration: a critical role for molecular chaperones? Neuron 35, 9-12.

Mucke, L., Masliah, E., Yu, G. Q., Mallory, M., Rockenstein, E. M., Tatsuno, G., Hu, K., Kholodenko, D., Johnson-Wood, K. \& McConlogue, L. (2000). High-level neuronal expression of abeta 1-42 in wild-type human amyloid protein precursor transgenic mice: synaptotoxicity without plaque formation. Journal of Neuroscience 20, 4050-4058.

Nakano, R., Inuzuka, T., Kikugawa, K., Takahashi, H., Sakimura, K., Fujil, J., Taniguchi, N. \& Tsuji, S. (1996). Instability of mutant $\mathrm{Cu} / \mathrm{Zn}$ superoxide dismutase (Ala4Thr) associated with familial amyotrophic lateral sclerosis. Neuroscience Letters 211, 129-131.

Naslund, J., Haroutunian, V., Mohs, R., Davis, K. L., Davies, P., Greengard, P. \& Buxbaum, J. D. (2000). Correlation between elevated levels of amyloid betapeptide in the brain and cognitive decline. Journal of the American Medical Association 283, 1571-1577.

Nilsberth, C., Westlind-Danielsson, A., Eckman, C. B., Condron, M. M., Axelman, K., Forsell, C., Stenh, C., Luthman, J., Teplow, D. B., Younkin, S. G., Naslund, J. \& Lannfelt, L. (2001). The 'Arctic' APP mutation (E693G) causes Alzheimer's disease by enhanced Abeta protofibril formation. Nature Neuroscience 4, 887-893.

O’brien, T. D., Butler, A. E., Roche, P. C., Johnson, K. H. \& ButLer, P. C. (1994). Islet amyloid polypeptide in human insulinomas. Evidence for intracellular amyloidogenesis. Diabetes 43, 329-336.

O’nuallain, B. \& Wetzel, R. (2002). Conformational Abs recognizing a generic amyloid fibril epitope. Proceeding. of the National Academy of Sciences USA 99, 1485-1490.

Olofsson, A., Hebert, H. \& Thelestam, M. (1993). The projection structure of perfringolysin $\mathrm{O}$ (Clostridium perfringens theta-toxin). FEBS Letters 319, 125-127.

Orlova, E. V., Rahman, M. A., Gowen, B., Volynski, K. E., Ashton, A. C., Manser, C., Van Heel, M. \& UshKaryov, Y. A. (2000). Structure of alpha-latrotoxin oligomers reveals that divalent cation-dependent tetramers form membrane pores. Nature Structural Biology 7, $48-53$.

Pandey, N., Schmidt, R. E. \& Galvin, J. E. (2006). The alpha-synuclein mutation E46K promotes aggregation in cultured cells. Experimental Neurology 197, 515-520.

Panov, A. V., Gutekunst, C. A., Leavitt, B. R., Hayden, M. R., Burke, J. R., Strittmatter, W. J. \& Greenamyre, J. T. (2002). Early mitochondrial calcium defects in Huntington's disease are a direct effect of polyglutamines. Nature Neuroscience 5, 731-736.

Parbhu, A., Lin, H., Thimm, J. \& Lal, R. (2002). Imaging real-time aggregation of amyloid beta protein (1-42) by atomic force microscopy. Peptides 23, 1265-1270.

Park, J. Y. \& Lansbury JR., P. T. (2003). Beta-synuclein inhibits formation of alpha-synuclein protofibrils: a possible therapeutic strategy against Parkinson's disease. Biochemistry 42, 3696-3700.

Pillot, T., Drouet, B., Pincon-Raymond, M., Vandekerckhove, J., Rosseneu, M. \& Chambaz, J. (2000). A nonfibrillar form of the fusogenic prion protein fragment [118-135] induces apoptotic cell death in rat cortical neurons. Journal of Neurochemistry 75, 2298-2308.

Pillot, T., Lins, L., Goethals, M., Vanloo, B., Baert, J., Vandekerckhove, J., Rosseneu, M. \& Brasseur, R. 
(1997). The 118-135 peptide of the human prion protein forms amyloid fibrils and induces liposome fusion. Journal of Molecular Biology 274, 381-393.

Pitschke, M., Prior, R., Haupt, M. \& Riesner, D. (1998). Detection of single amyloid beta-protein aggregates in the cerebrospinal fluid of Alzheimer's patients by fluorescence correlation spectroscopy. Nature Medicine 4, 832-834.

Podlisny, M. B., Ostaszewski, B. L., Squazzo, S. L., Koo, E. H., Rydell, R. E., Teplow, D. B. \& Selkoe, D. J. (1995). Aggregation of secreted amyloid beta-protein into sodium dodecyl sulfate-stable oligomers in cell culture. Journal of Biological Chemistry 270, 9564-9570.

Poirier, M. A., Li, H., Macosko, J., Cai, S., Amzel, M. \& Ross, C. A. (2002). Huntingtin spheroids and protofibrils as precursors in polyglutamine fibrilization. Journal of Biological Chemistry 277, 41032-41037.

Pollanen, M. S., Dickson, D. W. \& Bergeron, C. (1993). Pathology and biology of the Lewy body. Journal of Neuropathology \& Experimental Neurology 52, 183-191.

Polymeropoulos, M. H., Lavedan, C., Leroy, E., Ide, S. E., Dehejia, A., Dutra, A., Pike, B., Root, H., Rubenstein, J., Boyer, R., Stenroos, E. S., Chandrasekharappa, S., Athanassiadou, A., Papapetropoulos, T., Johnson, W. G., Lazzarini, A. M., Duvoisin, R. C., Di Iorio, G., Golbe, L. I. \& Nussbaum, R. L. (1997). Mutation in the alphasynuclein gene identified in families with Parkinson's disease. Science 276, 2045-2047.

Porat, Y., Kolusheva, S., Jelinek, R. \& Gazit, E. (2003). The human islet amyloid polypeptide forms transient membrane-active prefibrillar assemblies. Biochemistry 42, 10971-10977.

Pountney, D. L., Lowe, R., Quilty, M., Vickers, J. C., Voelcker, N. H. \& GAI, W. P. (2004). Annular alphasynuclein species from purified multiple system atrophy inclusions. Journal of Neurochemistry 90, 502-512.

Quist, A., Doudevski, I., Lin, H., Azimova, R., Ng, D., Frangione, B., Kagan, B., Ghiso, J. \& Lal, R. (2005). Amyloid ion channels: a common structural link for protein-misfolding disease. Proceedings of the National Academy of Sciences USA 102, 10427-10432.

Rajan, R. S., Illing, M. E., Bence, N. F. \& Kopito, R. R. (2001). Specificity in intracellular protein aggregation and inclusion body formation. Proceedings of the National Academy of Sciences USA 98, 13060-13065.

Rakhit, R., Crow, J. P., Lepock, J. R., Kondejewski, L. H., Cashman, N. R. \& Chakrabartty, A. (2004). Monomeric $\mathrm{Cu} / \mathrm{Zn}$ superoxide dismutase is a common misfolding intermediate in the oxidation models of sporadic and familial ALS. Journal of Biological Chemistry 279, 15499-15504.

Rakhit, R., Cunningham, P., Furtos-Matei, A., Dahan, S., Qi, X. F., Crow, J. P., Cashman, N. R., Kondejewski, L. H. \& Chakrabartty, A. (2002). Oxidation-induced misfolding and aggregation of superoxide dismutase and its implications for amyotrophic lateral sclerosis. Journal of Biological Chemistry 277, 47551-47556.

Ray, S. S., Nowak, R. J., Strokovich, K., Brown Jr., R. H, Walz, T. \& Lansbury JR., P. T. (2004). An intersubunit disulfide bond prevents in vitro aggregation of a superoxide dismutase-1 mutant linked to familial amytrophic lateral sclerosis. Biochemistry 43, 4899-4905.

Reixach, N., Deechongkit, S., Jiang, X., Kelly, J. W. \& Buxbaum, J. N. (2004). Tissue damage in the amyloidoses: transthyretin monomers and nonnative oligomers are the major cytotoxic species in tissue culture. Proceedings of the National Academy of Sciences USA 101, 2817-2822.

Rhee, S. K., Quist, A. P. \& Lal, R. (1998). Amyloid beta protein-(1-42) forms calcium-permeable, $\mathrm{Zn}^{2+}$ sensitive channel. Journal of Biological Chemistry 273, 13379-13382.

Rhondes, E. \& Gafni, A. (2003). Micelle formation by a fragment of human islet amyloid polypeptide. Biophysical Journal 84, 3480-3487.

Riesner, D., Kellings, K., Post, K., Wille, H., Serban, H., Groth, D., Baldwin, M. A. \& Prusiner, S. B. (1996). Disruption of prion rods generates 10-nm spherical particles having high alpha-helical content and lacking scrapie infectivity. Journal of Virology 70, 1714-1722.

Rochet, J. C., Conway, K. A. \& Lansbury Jr., P. T. (2000). Inhibition of fibrillization and accumulation of prefibrillar oligomers in mixtures of human and mouse alpha-synuclein. Biochemistry 39, 10619-10626.

Rochet, J. C. \& Lansbury Jr., P. T. (2000). Amyloid fibrillogenesis: themes and variations. Current Opinion in Structural Biology 10, 60-68.

Rockenstein, E., Hansen, L. A., Mallory, M., Trojanowski, J. Q., Galasko, D. \& Masliah, E. (2001). Altered expression of the synuclein family mRNA in Lewy body and Alzheimer's disease. Brain Research 914, 48-56.

Rodriguez, J. A., Valentine, J. S., Eggers, D. K., Roe, J. A., Tiwari, A., Brown Jr., R. H. \& Hayward, L. J. (2002). Familial amyotrophic lateral sclerosis-associated mutations decrease the thermal stability of distinctly metallated species of human copper/zinc superoxide dismutase. Journal of Biological Chemistry 277, 1593215937.

Roher, A. E., Chaney, M. O., Kuo, Y. M., Webster, S. D., Stine, W. B., Haverkamp, L. J., Woods, A. S., Cotter, R. J., Tuohy, J. M., Krafft, G. A., Bonnell, B. S. \& Emmerling, M. R. (1996). Morphology and toxicity of Abeta-(1-42) dimer derived from neuritic and vascular amyloid deposits of Alzheimer's disease. Journal of Biological Chemistry 271, 20631-20635.

Rosen, A. D. (1978). Amyotrophic lateral sclerosis. Clinical features and prognosis. Archives of Neurology 35, 638-642. 
Rosen, D. R., Siddique, T., Patterson, D., Figlewicz, D. A., Sapp, P., Hentati, A., Donaldson, D., Goto, J., O'regan, J. P., Deng, H. X., et al. (1993). Mutations in $\mathrm{Cu} / \mathrm{Zn}$ superoxide dismutase gene are associated with familial amyotrophic lateral sclerosis. Nature 362, 59-62.

Ross, C. A. \& Pickart, C. M. (2004). The ubiquitin-proteasome pathway in Parkinson's disease and other neurodegenerative diseases. Trends in Cell Biology 14, 703-711.

Rossi, D., Cozzio, A., Flechsig, E., Klein, M. A., Rulicke, T., Aguzzi, A. \& Weissmann, C. (2001). Onset of ataxia and Purkinje cell loss in $\operatorname{PrP}$ null mice inversely correlated with $\mathrm{Dpl}$ level in brain. EMBO Journal 20, 694-702.

Rubenstein, R., Merz, P. A., Kascsak, R. J., Carp, R. I., Scalici, C. L., FAma, C. L. \& Wisniewski, H. M. (1987). Detection of scrapie-associated fibrils (SAF) and SAF proteins from scrapie-affected sheep. Journal of Infectious Diseases 156, 36-42.

Sanderson, K. L., Butler, L. \& Ingram, V. M. (1997). Aggregates of a beta-amyloid peptide are required to induce calcium currents in neuron-like human teratocarcinoma cells: relation to Alzheimer's disease. Brain Research 744, 7-14.

Sanghera, N. \& Pinheiro, T. J. (2002). Binding of prion protein to lipid membranes and implications for prion conversion. Journal of Molecular Biology 315, 1241-1256.

Scherzinger, E., Sittler, A., Schweiger, K., Heiser, V., Lurz, R., Hasenbank, R., Bates, G. P., Lehrach, H. \& WANKer, E. E. (1999). Self-assembly of polyglutaminecontaining huntingtin fragments into amyloid-like fibrils: implications for Huntington's disease pathology. Proceedings of the National Academy of Sciences USA 96, 4604-4609.

Schubert, U., Anton, L. C., Gibbs, J., Norbury, C. C., Yewdell, J. W. \& Bennink, J. R. (2000). Rapid degradation of a large fraction of newly synthesized proteins by proteasomes. Nature 404, 770-774.

Sekiya, K., Satoh, R., Danbara, H. \& Futaesaku, Y. (1993). A ring-shaped structure with a crown formed by streptolysin $\mathrm{O}$ on the erythrocyte membrane. Journal of Bacteriology 175, 5953-5961.

Selkoe, D. J. (1994). Cell biology of the amyloid betaprotein precursor and the mechanism of Alzheimer's disease. Annual Reviews of Cell Biology 10, 373-403.

Sellman, B. R., Kagan, B. L. \& Tweten, R. K. (1997). Generation of a membrane-bound, oligomerized prepore complex is necessary for pore formation by Clostridium septicum alpha toxin. Molecular Microbiology 23, 551-558.

Serpell, L. C., Sunde, M., Benson, M. D., Tennent, G. A., Pepys, M. B. \& Fraser, P. E. (2000). The protofilament substructure of amyloid fibrils. Journal of Molecular Biology 300, 1033-1039.
Sharon, R., Bar-Joseph, I., Frosch, M. P., Walsh, D. M., Hamilton, J. A. \& Selkoe, D. J. (2003a). The formation of highly soluble oligomers of alpha-synuclein is regulated by fatty acids and enhanced in Parkinson's disease. Neuron 37, 583-595.

Sharon, R., Bar-Joseph, I., Mirick, G. E., Serhan, C. N. \& Selkoe, D. J. (2003b). Altered fatty acid composition of dopaminergic neurons expressing alpha-synuclein and human brains with alpha-synucleinopathies. Journal of Biological Chemistry 278, 49874-49881.

Sharon, R., Goldberg, M. S., Bar-Josef, I., Betensky, R. A., Shen, J. \& Selkoe, D. J. (2001). alpha-Synuclein occurs in lipid-rich high molecular weight complexes, binds fatty acids, and shows homology to the fatty acidbinding proteins. Proceedings of the National Academy of Sciences USA 98, 9110-9115.

Sharpe, J. C. \& London, E. (1999). Diphtheria toxin forms pores of different sizes depending on its concentration in membranes: probable relationship to oligomerization. Journal of Membrane Biology 171, 209-221.

Shibata, N., Hirano, A., Kobayashi, M., Siddique, T., Deng, H. X., Hung, W. Y., Kato, T. \& Asayama, K. (1996). Intense superoxide dismutase-1 immunoreactivity in intracytoplasmic hyaline inclusions of familial amyotrophic lateral sclerosis with posterior column involvement. Journal of Neuropathology \& Experimental Neurology 55, 481-490.

Shimura, H., Schlossmacher, M. G., Hattori, N., Frosch, M. P., Trockenbacher, A., Schneider, R., Mizuno, Y., Kosik, K. S. \& Selkoe, D. J. (2001). Ubiquitination of a new form of alpha-synuclein by parkin from human brain: implications for Parkinson's disease. Science 293, 263-269.

Shtilerman, M. D., Ding, T. T. \& Lansbury Jr., P. T. (2002). Molecular crowding accelerates fibrillization of alpha-synuclein: could an increase in the cytoplasmic protein concentration induce Parkinson's disease? Biochemistry 41, 3855-3860.

Shults, C. W. (2006). Lewy bodies. Proceedings of the National Academy of Sciences USA 103, 1661-1668.

Silveira, J. R., Raymond, G. J., Hughson, A. G., Race, R. E., Sim, V. L., Hayes, S. F. \& Caughey, B. (2005). The most infectious prion protein particles. Nature 437, 257-261.

Singer, S. J. \& DewjI, N. N. (2006). Evidence that Perutz's double-beta-stranded subunit structure for beta-amyloids also applies to their channel-forming structures in membranes. Proceedings of the National Academy of Sciences USA 103, 1546-1550.

Singleton, A., Myers, A. \& Hardy, J. (2004). The law of mass action applied to neurodegenerative disease: a hypothesis concerning the aetiology and pathogenesis of complex diseases. Human Molecular Genetics 13, R123-R126.

Singleton, A. B., Farrer, M., Johnson, J., Singleton, A., Hague, S., Kachergus, J., Hulihan, M., Peuralinna, 
T., Dutra, A., Nussbaum, R., Lincoln, S., Crawley, A., Hanson, M., Maraganore, D., Adler, C., Cookson, M. R., Muenter, M., Baptista, M., Miller, D., Blancato, J., Hardy, J. \& Gwinn-Hardy, K. (2003). alpha-Synuclein locus triplication causes Parkinson's disease. Science 302, 841.

Smith, W. W., Margolis, R. L., Li, X., Troncoso, J. C., Lee, M. K., Dawson, V. L., Dawson, T. M., Iwatsubo, T. \& Ross, C. A. (2005). Alpha-synuclein phosphorylation enhances eosinophilic cytoplasmic inclusion formation in SH-SY5Y cells. Journal of Neuroscience 25, 5544-5552.

Snyder, H., Mensah, K., Theisler, C., Lee, J., MatouscheK, A. \& Wolozin, B. (2003). Aggregated and monomeric alpha-synuclein bind to the S6' proteasomal protein and inhibit proteasomal function. Journal of Biological Chemistry 278, 11753-11759.

Sokolowski, F., Modler, A. J., Masuch, R., Zirwer, D., Baier, M., Lutsch, G., Moss, D. A., Gast, K. \& NAumann, D. (2003). Formation of critical oligomers is a key event during conformational transition of recombinant syrian hamster prion protein. Journal of Biological Chemistry 278, 40481-40492.

Song, L., Hobaugh, M. R., Shustak, C., Cheley, S., Bayley, H. \& Gouaux, J. E. (1996). Structure of staphylococcal alpha-hemolysin, a heptameric transmembrane pore. Science 274, 1859-1866.

Soti, C. \& Csermely, P. (2002). Chaperones and aging: role in neurodegeneration and in other civilizational diseases. Neurochemistry International 41, 383-389.

Sousa, M. M., Cardoso, I., Fernandes, R., Guimaraes, A. \& Saraiva, M. J. (2001). Deposition of transthyretin in early stages of familial amyloidotic polyneuropathy: evidence for toxicity of nonfibrillar aggregates. American Journal of Pathology 159, 1993-2000.

Sousa, M. M., Fernandes, R., Palha, J. A., Taboada, A., Vieira, P. \& Saraiva, M. J. (2002). Evidence for early cytotoxic aggregates in transgenic mice for human transthyretin Leu55Pro. American Journal of Pathology 161, 1935-1948.

Spillantini, M. G., Crowther, R. A., Jakes, R., Cairns, N. J., Lantos, P. L. \& Goedert, M. (1998a). Filamentous alpha-synuclein inclusions link multiple system atrophy with Parkinson's disease and dementia with Lewy bodies. Neuroscience Letters 251, 205-208.

Spillantini, M. G., Crowther, R. A., Jakes, R., Hasegawa, M. \& Goedert, M. (1998b). alphaSynuclein in filamentous inclusions of Lewy bodies from Parkinson's disease and dementia with lewy bodies. Proceedings of the National Academy of Sciences USA 95, 6469-6473.

Srinivasan, R., Jones, E. M., Liu, K., Ghiso, J., Marchant, R. E. \& Zagorski, M. G. (2003). pH-dependent amyloid and protofibril formation by the ABri peptide of familial British dementia. Journal of Molecular Biology 333, 1003-1023.
Srinivasan, R., Marchant, R. \& Zagorski, M. (2004). ABri peptide associated with familial British dementia forms pore-like protofibrillar structures. Amyloid 11, $10-13$.

Stefani, M. \& Dobson, C. M. (2003). Protein aggregation and aggregate toxicity: new insights into protein folding, misfolding diseases and biological evolution. Journal of Molecular Medicine 81, 678-699.

Stege, G. J., Renkawek, K., Overkamp, P. S., Verschuure, P., Van Rijk, A. F., Rejjnen-Aalbers, A., Boelens, W. C., Bosman, G. J. \& De Jong, W. W. (1999). The molecular chaperone alphaB-crystallin enhances amyloid beta neurotoxicity. Biochemical and Biophysical Research Communications 262, 152-156.

Stine Jr., W. B., Dahlgren, K. N., Krafft, G. A. \& LADU, M. J. (2003). In vitro characterization of conditions for amyloid-beta peptide oligomerization and fibrillogenesis. Journal of Biological Chemistry 278, 11612-11622.

Sunde, M., Serpell, L. C., Bartlam, M., Fraser, P. E., Pepys, M. B. \& Blake, C. C. (1997). Common core structure of amyloid fibrils by synchrotron X-ray diffraction. Journal of Molecular Biology 273, 729-739.

Supattapone, S., Bosque, P., Muramoto, T., Wille, H., Aagaard, C., Peretz, D., Nguyen, H. O., Heinrich, C., Torchia, M., Safar, J., Cohen, F. E., Dearmond, S. J., Prusiner, S. B. \& Scott, M. (1999). Prion protein of 106 residues creates an artifical transmission barrier for prion replication in transgenic mice. Cell 96, 869-878.

Tadjibaeva, G., Sabirov, R. \& Tomita, T. (2000). Flammutoxin, a cytolysin from the edible mushroom Flammulina velutipes, forms two different types of voltage-gated channels in lipid bilayer membranes. Biochimica et Biophysica Acta 1467, 431-443.

Tanaka, Y., Engelender, S., Igarashi, S., Rao, R. K., Wanner, T., TAnzi, R. E., Sawa, A., Dawson, V. L., Dawson, T. M. \& Ross, C.A. (2001). Inducible expression of mutant alpha-synuclein decreases proteasome activity and increases sensitivity to mitochondria-dependent apoptosis. Human Molecular Genetics 10, 919-926.

Taylor, J. P., Tanaka, F., Robitschek, J., Sandoval, C. M., Taye, A., Markovic-Plese, S. \& Fischbeck, K. H. (2003). Aggresomes protect cells by enhancing the degradation of toxic polyglutamine-containing protein. Human Molecular Genetics 12, 749-757.

Teng, M. H., Yin, J. Y., Vidal, R., Ghiso, J., Kumar, A., Rabenou, R., Shah, A., Jacobson, D. R., Tagoe, C., Gallo, G. \& Buxbaum, J. (2001). Amyloid and nonfibrillar deposits in mice transgenic for wild-type human transthyretin: a possible model for senile systemic amyloidosis. Laboratory Investigation 81, 385-396.

Terry, R. D., Masliah, E., Salmon, D. P., Butters, N., Deteresa, R., Hill, R., Hansen, L. A. \& Katzman, R. (1991). Physical basis of cognitive alterations in 
Alzheimer's disease: synapse loss is the major correlate of cognitive impairment. Annals of Neurology 30, 572-580.

Tiwari, A. \& Hayward, L. J. (2003). Familial amyotrophic lateral sclerosis mutants of copper/zinc superoxide dismutase are susceptible to disulfide reduction. Journal of Biological Chemistry 278, 5984-5992.

Tompkins, M. M. \& Hill, W. D. (1997). Contribution of somal Lewy bodies to neuronal death. Brain Research 775, 24-29.

Townsend, M., Shankar, G. M., Mehta, T., Walsh, D. M. \& Selkoe, D. J. (2006). Effects of secreted oligomers of amyloid $\beta$-protein on hippocampal synaptic plasticity: a potent role for trimers. Journal of Physiology 572, 477-492.

Turner, B. J., Lopes, E. C. \& Cheema, S. S. (2003). Neuromuscular accumulation of mutant superoxide dismutase 1 aggregates in a transgenic mouse model of familial amyotrophic lateral sclerosis. Neuroscience Letters 350, 132-136.

Urushitani, M., Kurisu, J., Tsukita, K. \& Takahashi, R. (2002). Proteasomal inhibition by misfolded mutant superoxide dismutase 1 induces selective motor neuron death in familial amyotrophic lateral sclerosis. Journal of Neurochemistry 83, 1030-1042.

Uryu, K., Giasson, B. I., Longhi, L., Martinez, D., Murray, I., Conte, V., Nakamura, M., Saatman, K., Talbot, K., Horiguchi, T., Mcintosh, T., Lee, V. M. \& Trojanowski, J. Q. (2003). Age-dependent synuclein pathology following traumatic brain injury in mice. Experimental Neurology 184, 214-224.

Valeva, A., Palmer, M. \& Bhakdi, S. (1997). Staphylococcal alpha-toxin: formation of the heptameric pore is partially cooperative and proceeds through multiple intermediate stages. Biochemistry 36, 13298-13304.

Vendrely, C., Valadie, H., Bednarova, L., Cardin, L., Pasdeloup, M., Cappadoro, J., Bednar, J., Rinaudo, M. \& JAmin, M. (2005). Assembly of the full-length recombinant mouse prion protein I. Formation of soluble oligomers. Biocbimica et Biophysica Acta 1724, 355-366.

Vidal, R., Frangione, B., Rostagno, A., Mead, S., Revesz, T., Plant, G. \& Ghiso, J. (1999). A stop-codon mutation in the BRI gene associated with familial British dementia. Nature 399, 776-781.

Volles, M. J. \& Lansbury Jr., P. T. (2002). Vesicle permeabilization by protofibrillar alpha-synuclein is sensitive to Parkinson's disease-linked mutations and occurs by a pore-like mechanism. Biochemistry 41, 4595-4602.

Volles, M. J. \& Lansbury Jr., P. T. (2003). Zeroing in on the pathogenic form of alpha-synuclein and its mechanism of neurotoxicity in Parkinson's disease. Biochemistry 42, 7871-7878.

Volles, M. J., Lee, S. J., Rochet, J. C., Shtilerman, M. D., Ding, T. T., Kessler, J. C. \& Lansbury Jr., P. T. (2001). Vesicle permeabilization by protofibrillar alpha-synuclein: implications for the pathogenesis and treatment of Parkinson's disease. Biochemistry 40, 7812-7819.

Wacker, J. L., Zareie, M. H., Fong, H., Sarikaya, M. \& Muchowski, P. J. (2004). Hsp70 and Hsp40 attenuate formation of spherical and annular polyglutamine oligomers by partitioning monomer. Nature Structural o Molecular Biology 11, 1215-1222.

Walker, B., Krishnasastry, M., Zorn, L. \& Bayley, H. (1992). Assembly of the oligomeric membrane pore formed by Staphylococcal alpha-hemolysin examined by truncation mutagenesis. Journal of Biological Chemistry 267, 21782-21786.

Wallace, A. J., Stillman, T. J., Atkins, A., Jamieson, S. J., Bullough, P. A., Green, J. \& Artymiuk, P. J. (2000). E. coli hemolysin E (HlyE, ClyA, SheA): X-ray crystal structure of the toxin and observation of membrane pores by electron microscopy. Cell 100, 265-276.

Walsh, D. M., Hartley, D. M., Kusumoto, Y., Fezoui, Y., Condron, M. M., Lomakin, A., Benedek, G. B., Selkoe, D. J. \& Teplow, D. B. (1999). Amyloid betaprotein fibrillogenesis. Structure and biological activity of protofibrillar intermediates. Journal of Biological Chemistry 274, 25945-25952.

Walsh, D. M., Klyubin, I., Fadeeva, J. V., Cullen, W. K., Anwyl, R., Wolfe, M. S., Rowan, M. J. \& SELKoE, D. J. (2002). Naturally secreted oligomers of amyloid beta protein potently inhibit hippocampal long-term potentiation in vivo. Nature 416, 535-539.

Walsh, D. M., Lomakin, A., Benedek, G. B., Condron, M. M. \& Teplow, D. B. (1997). Amyloid beta-protein fibrillogenesis. Detection of a protofibrillar intermediate. Journal of Biological Chemistry 272, 22364-22372.

Walsh, D. M., Tseng, B. P., Rydel, R. E., Podlisny, M. B. \& Selkoe, D. J. (2000). The oligomerization of amyloid beta-protein begins intracellularly in cells derived from human brain. Biochemistry 39, 10831-10839.

Wang, H. W., Pasternak, J. F., Kuo, H., Ristic, H., Lambert, M. P., Chromy, B., Viola, K. L., Klein, W. L., Stine, W. B., Krafft, G. A. \& Trommer, B. L. (2002a). Soluble oligomers of beta amyloid (1-42) inhibit long-term potentiation but not long-term depression in rat dentate gyrus. Brain Research $\mathbf{9 2 4}$, 133-140.

Wang, L., Lashuel, H. A., Walz, T. \& Colon, W. (2002b). Murine apolipoprotein serum amyloid A in solution forms a hexamer containing a central channel. Proceedings of the National Academy of Sciences USA 99, 15947-15952.

Wang, Q., Walsh, D. M., Rowan, M. J., Selkoe, D. J. \& ANWYL, R. (2004). Block of long-term potentiation by naturally secreted and synthetic amyloid beta-peptide in hippocampal slices is mediated via activation of the kinases c-Jun $\mathrm{N}$-terminal kinase, cyclin-dependent kinase 5 , and p38 mitogen-activated protein kinase as well as 
metabotropic glutamate receptor type 5. Journal of Neuroscience 24, 3370-3378.

Watanabe, M., Dykes-Hoberg, M., Culotta, V. C., Price, D. L., Wong, P. C. \& Rothstein, J. D. (2001). Histological evidence of protein aggregation in mutant SOD1 transgenic mice and in amyotrophic lateral sclerosis neural tissues. Neurobiology of Disease Journal $\mathbf{8}$, 933-941.

Watase, K., Weeber, E. J., Xu, B., Antalffy, B., YuvaPaylor, L., Hashimoto, K., Kano, M., Atkinson, R., Sun, Y., Armstrong, D. L., Sweatt, J. D., Orr, H. T., PAylor, R. \& Zoghbi, H. Y. (2002). A long CAG repeat in the mouse Sca1 locus replicates SCA1 features and reveals the impact of protein solubility on selective neurodegeneration. Neuron 34, 905-919.

Weinreb, P. H., Zhen, W., Poon, A. W., Conway, K. A. \& Lansbury JR., P. T. (1996). NACP, a protein implicated in Alzheimer's disease and learning, is natively unfolded. Biochemistry 35, 13709-13715.

Wetzel, R. (1994). Mutations and off-pathway aggregation of proteins. Trends in Biotechnology 12, 193-198.

Whalen, B. M., Selkoe, D. J. \& Hartley, D. M. (2005). Small non-fibrillar assemblies of amyloid beta-protein bearing the Arctic mutation induce rapid neuritic degeneration. Neurobiology of Disease Journal 20, 254-266.

White, J.A., Manelli, A. M., Holmberg, K. H., Van Eldik, L. J. \& LADU, M. J. (2005). Differential effects of oligomeric and fibrillar amyloid-beta 1-42 on astrocytemediated inflammation. Neurobiology of Disease Journal 18, 459-465.

Wood, W. G., Schroeder, F., Igbavboa, U., Avdulov, N. A. \& Chochina, S. V. (2002). Brain membrane cholesterol domains, aging and amyloid beta-peptides. Neurobiology of Aging 23, 685-694.

Xu, J., Kao, S. Y., Lee, F. J., Song, W., Jin, L. W. \& Yankner, B. A. (2002). Dopamine-dependent neurotoxicity of alpha-synuclein: a mechanism for selective neurodegeneration in Parkinson disease. Nature Medicine 8, 600-606.

Yong, W., Lomakin, A., Kirkitadze, M. D., Teplow, D. B., Chen, S. H. \& BenedeK, G. B. (2002). Structure determination of micelle-like intermediates in amyloid beta -protein fibril assembly by using small angle neutron scattering. Proceedings of the National Academy of Sciences USA 99, 150-154.

Zarranz, J. J., Alegre, J., Gomez-Esteban, J. C., Lezcano, E., Ros, R., Ampuero, I., Vidal, L., Hoenicka, J., Rodriguez, O., Atares, B., Llorens, V., Tortosa, E. G., Del Ser, T., Munoz, D. G. \& De Yebenes, J. G. (2004). The new mutation, E46K, of alpha-synuclein causes parkinson and Lewy body dementia. Annals of Neurology 55, 164-173.

Zhang, Y., McLaughlin, R., Goodyer, C. \& Leblanc, A. (2002). Selective cytotoxicity of intracellular amyloid beta peptide 1-42 through p53 and Bax in cultured primary human neurons. Journal of Cell Biology 156, 519-529.

Zhu, M. \& FInK, A. L. (2003). Abstract Viewer/Itinerary Planner. Washington, DC: Society for Neuroscience, Program No. 132.12.

Zhu, M., Rajmani, S., Kaylor, J., Han, S., Zhou, F. \& FINK, A. L. (2004). The flavonoid baicalein inhibits fibrillation of alpha-synuclein and disaggregates existing fibrils. Journal of Biological Chemistry 279, 26846-26857.

Zitzer, A., Walev, I., Palmer, M. \& Bhakdi, S. (1995). Characterization of Vibrio cholerae El Tor cytolysin as an oligomerizing pore-forming toxin. Medical Microbiology and Immunology (Berlin) 184, 37-44.

Zoghis, H. Y. \& OrR, H. T. (2000). Glutamine repeats and neurodegeneration. Annual Review of Neuroscience 23, 217-247. 